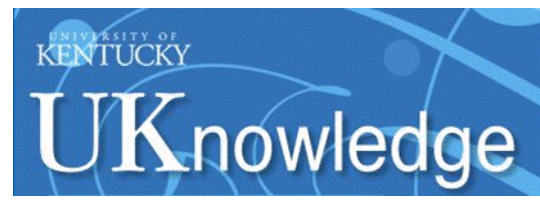

University of Kentucky

UKnowledge

\title{
Educational Test Scores, Education Spending, and Productivity in Public Education: National Trends and Evidence Across States and Over Time, 1990-2015
}

John Garen

University of Kentucky, john.garen@uky.edu

Rex Bray

Harvard University

Follow this and additional works at: https://uknowledge.uky.edu/isfe_papers

Part of the Education Economics Commons, and the Public Economics Commons

Right click to open a feedback form in a new tab to let us know how this document benefits you.

\section{Repository Citation}

Garen, John and Bray, Rex, "Educational Test Scores, Education Spending, and Productivity in Public Education: National Trends and Evidence Across States and Over Time, 1990-2015" (2018). Institute for the Study of Free Enterprise Working Papers. 10.

https://uknowledge.uky.edu/isfe_papers/10

This Research Paper is brought to you for free and open access by the Institute for the Study of Free Enterprise at UKnowledge. It has been accepted for inclusion in Institute for the Study of Free Enterprise Working Papers by an authorized administrator of UKnowledge. For more information, please contact UKnowledge@lsv.uky.edu. 


\title{
Educational Test Scores, Education Spending, and Productivity in Public Education: National Trends and Evidence Across States and Over Time, 1990-2015
}

\section{John Garen \\ Rex Bray}

January 2018

Institute for the Study of Free Enterprise

Working Paper 20

\author{
University of Kentucky \\ 244 Gatton College of Business and Economics \\ Lexington, KY 40506-0034 \\ http://isfe.uky.edu/
}




\title{
Educational Test Scores, Education Spending, and Productivity in Public Education: National Trends and Evidence Across States and Over Time, 1990 - 2015
}

\author{
John Garen \\ BB\&T Professor of Economics \\ University of Kentucky \\ Rex Bray \\ Harvard Law School
}

January 2018

\begin{abstract}
We examine national trends in educational funding, test score outcomes, and productivity as well as variations in funding and test scores over time and across states to assess how changes in educational spending are (or are not) related to changes in educational test score outcomes for states. National trends show small increases in test scores, large increases in educational funding (until the last recession), and a continued fall in educational productivity. The cross-state, over time analysis indicates a statistically significant but very small association of state funding to test scores; so small that large changes in funding have little effect on scores. This is consistent with the continued decline in educational productivity. We also find similar results for black students, implying that the increased funding has not served to reduce racial inequality. We suggest that the continued decline in productivity of public schools adds further reason to question the ability of non-competitive, public organizations to improve educational performance and to look for alternatives that embrace or emulate private-sector, competitive organizations.
\end{abstract}

*For helpful comments, we thank Aaron Yelowitz, Frank Scott, James Fackler, John Merrifield and session participants at the Southern Economic Association annual conference and the Association of Private Enterprise Education annual meetings. We are also grateful to the John H. Schnatter Institute for Free Enterprise and the BB\&T Program for the Study of Capitalism, both at the University of Kentucky, for support. 


\section{Introduction}

Concerns about the performance of traditional public schools have been with us for quite a number of years. Though disputes regarding school funding seem to occur regularly, the data are clear in showing increasing resources being devoted to public schools over the past several decades. The increasing use of resources has reinforced concerns regarding public school performance. Essentially, this is a question about what is being attained with the dollars spent on K-12 education.

Thus, an important aspect of this paper is to examine the relationship of school funding to student outcomes. A closely related concept is the productivity of education spending, i.e., educational "output" (or outcome) per dollar spent. In an examination of this question over ten years ago, Hoxby (2004) finds that the productivity of public education declined substantially by nearly 50 percent - from the 1970 s to 2000 . Her measure of educational outcomes is the National Assessment of Education Progress (NAEP) test scores. From 1970 to 2000, these scores hardly changed, yet inflation-adjusted, per-pupil spending almost doubled.

There have been some signs of improvement in the NAEP test scores in the 2000s, though these experiences have varied across states, as have changes in resources devoted to schools. Accordingly, this paper considers two related aspects of these issues. First, we update overall national trends on educational funding, test score outcomes, and productivity. Second, we examine variations in funding and test scores over time and across states to assess how changes in educational spending are (or are not) related to changes in educational test score outcomes for states.

Our findings regarding national trends show small increases in test scores, large increases in educational funding (until the last recession), and a continued fall in educational productivity. 
The cross-state, over time analysis indicates a statistically significant but very small association of state funding to test scores. Our preferred estimates imply that the magnitude is so small that higher funding of $\$ 1,000$ is associated with trivially higher NAEP test scores. ${ }^{1}$ This is consistent with the continued decline in productivity that we verify in the cross-state data. Also, note that we find the patterns for black students are essentially the same as for all students, implying that the increased funding has not served to raise minority outcomes and reduce racial inequality.

Hoxby (2004) suggests that the decline in the productivity of K-12 education is due to the decline of competition among jurisdictions for students and provides evidence to support this. Moreover, there is a good deal of literature regarding the incentive problems of governmentoperated organizations that face little competition, which characterizes most public schools. For an overview and discussion of this literature as it pertains to schools, see Garen (2016). The results of our paper are consistent with Hoxby (2004). Though it is appropriate to be cautious regarding causality with respect to funding and outcomes, the continued decline in productivity of public schools that we find adds further reason to question the ability of non-competitive, public organizations to improve educational performance and to look for alternatives that embrace or emulate private-sector, competitive organizations.

The question of the effect of school resources and spending on educational outcomes has a long history. Coleman (1966) was perhaps the first to do a broad-based examination of the importance of school resources in K-12 education, finding that other factors were much more critical. Hanushek (1986) reviews the empirical work that followed Coleman (1966), indicating that differences in school quality do not seem to reflect variations in expenditure, class size, or other commonly measured attributes of schools and teachers. A good deal of empirical work on

\footnotetext{
${ }^{1}$ See Merrifield (2009) for a related analysis. He takes extant estimates of the effects of resources on school outcomes and simulates the effect of substantially greater resources. He finds very small effects.
} 
this topic continued with improved data and more advanced methods. Later surveys by Hanushek (2003), Gustafsson (2003), and Glewwe (2013) find strong effects of teachers but an absence of consistent effects of school expenditures in reviews of research pertaining to many countries around the world. These lack-of-effects findings are the norm. However, there are some exceptions, and some studies find positive effects on the subsequent earnings and employment experiences of students "exposed" to higher education spending when young. See, for example, Jackson, Johnson, and Persico (2016), Fredriksson, Ockert, Oosterbeek (2013), and Card and Krueger (1992). Betts (1995), however, following a similar methodology, finds no effects of school resources, consistent with the bulk of the literature.

Our paper fits into this stream of research with focus on the recent experiences of states in the U.S. Though the small effects of expenditures on public school performance suggests an evaluation of alternative types of school organizations (e.g., charter schools and voucher programs), this is beyond the scope of this paper. The reader is referred to Garen (2016) for a discussion and critique of that literature.

The remainder of the paper is organized as follows. Section II discusses our measure of educational outcomes, as well as our data on school expenditures. We follow Hoxby (2004) and others in using the National Assessment of Educational Progress (NAEP) test scores to measure educational outcomes. Section III provides an update on and discussion of the long-term trend in productivity in education in the U.S. from 1971 to 2012. As we detail below, though test scores have improved in the recent past, spending rose even faster and productivity continues to decline. Section IV examines the data on test scores and spending by state and over time to assess the association of test score improvements with increased state spending. We find a positive and statistically significant association, though very small in magnitude, e.g., a $\$ 1,000$ increment to 
per pupil spending is associated with minimal changes in NAEP test scores. The findings for black students are approximately the same, indicating that the funding has not reduced racial inequality in test scores. We also find somewhat more robust effects of local funding relative to state and federal, though magnitudes remain small. The decline in educational productivity is also verified in the cross-state panel data. Lastly, section V concludes.

\section{Measuring Educational Outcomes}

We follow Hoxby (2004) in using the National Assessment of Educational Progress (NAEP) test scores as our measure of educational outcomes. We utilize the mathematics test scores and the reading test scores of $4^{\text {th }}$ and $8^{\text {th }}$ graders. The NAEP is the largest nationally representative and continuing assessment of the nation's students. Since NAEP assessments are administered uniformly using the same sets of test booklets across the nation, they provide a common measure of student achievement across the country. The assessments stay essentially the same from year to year, with only carefully documented changes to reflect changes in curriculum in the nation's schools. NAEP's long-term trend assessment is a national sample begun in the 1970s and currently is given every four years. The state assessments began in the 1990s and allows comparisons across states. It is now conducted every two years. These assessments are referred to as The Nation's Report Card. More detail is in National Center for Educational Statistics (2017).

The common measures across states and over time are a great advantage over other testbased data sets. Many states have conducted tests for a long time, but they are not consistent over time or across states. However, there are criticisms of test scores as measures of educational outcomes. Ultimately, the desired outcome from education is its enabling people to improve their lives. This can be through improvements in a variety of ways, such as school 
completion, improved earnings, higher levels of employment, better health, and other outcomes. As noted above, there are studies that relate the subsequent labor market experiences of people to their school environment when young. However, these data are often limited in scope. Also, the NAEP tests, and others like them, measure important aspects of cognitive skills. However, it is becoming increasingly recognized that non-cognitive skills, such as persistence, motivation, and dependability, have great importance in determining success in life. See Heckman, Stixrud, and Urzua (2006). NAEP test score outcomes only indirectly measure these attributes.

Nevertheless, it is well established that scores on tests similar to the NAEP are strongly correlated with a person's labor market earnings. See Currie and Thomas (2001), for example. Moreover, Hanushek, Ruhose, and Woessmann (2017) find that U.S. state GDP growth is related to the state's average NAEP test score. The NAEP test score outcomes measure something that matters.

We collect data on education spending and school enrollment from the National Center for Educational Statistics' Digest of Education Statistics. Several measures of spending are collected. We collect data on the total school revenue collected by the state, as well as the total from each source; local, state, or federal. We also obtain data on total expenditures, current expenditures, and instructional expenditures (available only since 1986). Each is expressed on a per pupil basis using enrollment data. It is also adjusted for inflation and expressed in constant 2016 dollars.

\section{National Trends in Scores, Spending, and Productivity}

This section presents national long-term trends in NAEP scores from NAEP's Long-Term Trend Assessment, along with national educational spending data from the Digest of Education 
Statistics. Test scores are national averages. Revenue and expenditure data are per pupil national averages.

Figure 1 presents a graph of the gains in NAEP reading scores since 1971 for both grade 4 and grade 8 . This is calculated by subtracting the 1971 score from the actual score in each year the test was given. ${ }^{2}$ The latest year available is 2012. The raw data for these computations is in appendix Table A1. The dashed (blue) line is for grade 4 and the solid (red) line represents grade 8. As can be seen, the gains in test scores are small, especially through the late 1990s. Grade 4 scores have improved through the 2000s. There is an uptick in grade 8 scores beginning in 2008 .

Figure 1

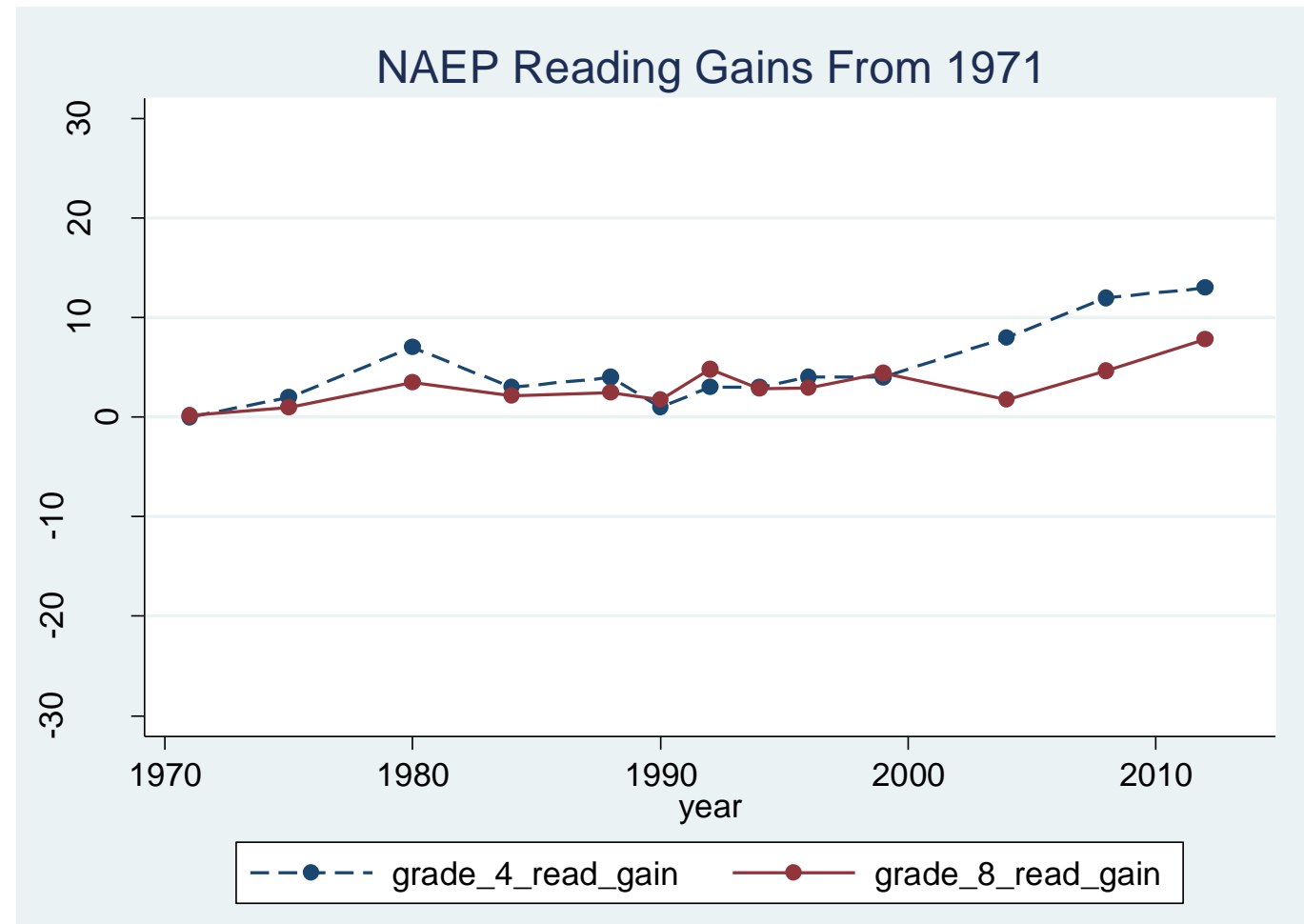

\footnotetext{
${ }^{2}$ The scale of this graph $(-30$ to +30$)$ is selected because the standard deviation of individual NAEP test scores is roughly 30 each year.
} 
Figure 2 shows similar calculations for grade 4 and grade 8 NAEP math scores. These are gains from 1978 since that is the first year the math tests were given. Again, the raw data is in appendix Table A1. Here, there is a persistent upward trend in test scores through most of this time period.

\section{Figure 2}

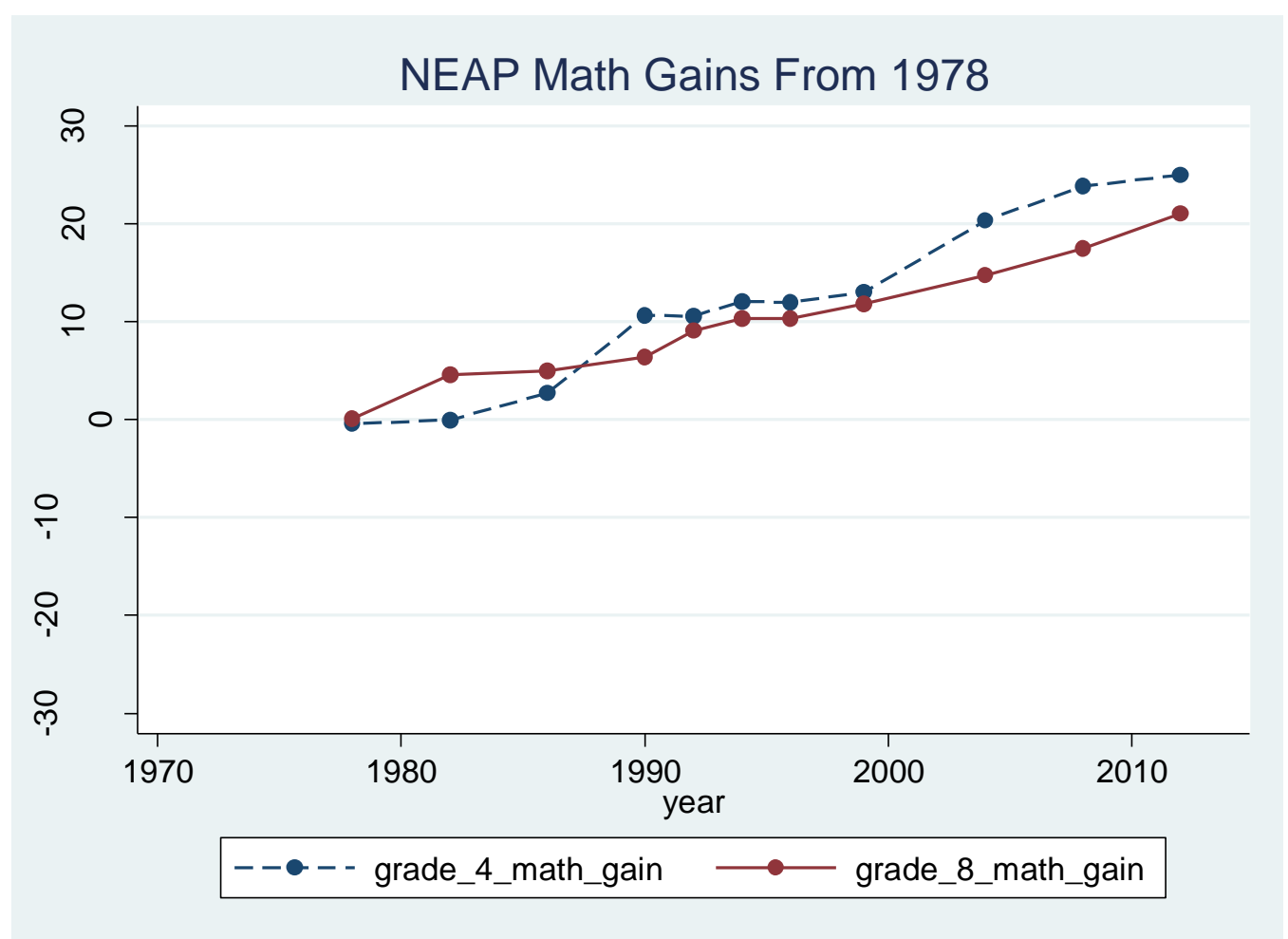

Figure 3 presents a graph of per pupil revenue and expenditure for public schools in the U.S. from 1971 to 2012. They are adjusted for inflation and expressed in 2016 dollars. The data for Figure 3, as well as Figures 4 and 5, are in appendix Table A2. In Figure 3, revenue per pupil is the dashed (blue) line and expenditure is the solid (red) line. They track one another very closely and their correlation coefficient is .9988. There is a strong and persistent upward trend. There have been only a handful of years until 2010 in which education revenue or expenditure 
fell or was unchanged. The declines in years 2010 to 2012 are due to the effects of the recent recession and the consequent reductions in state and local budgets.

\section{Figure 3}

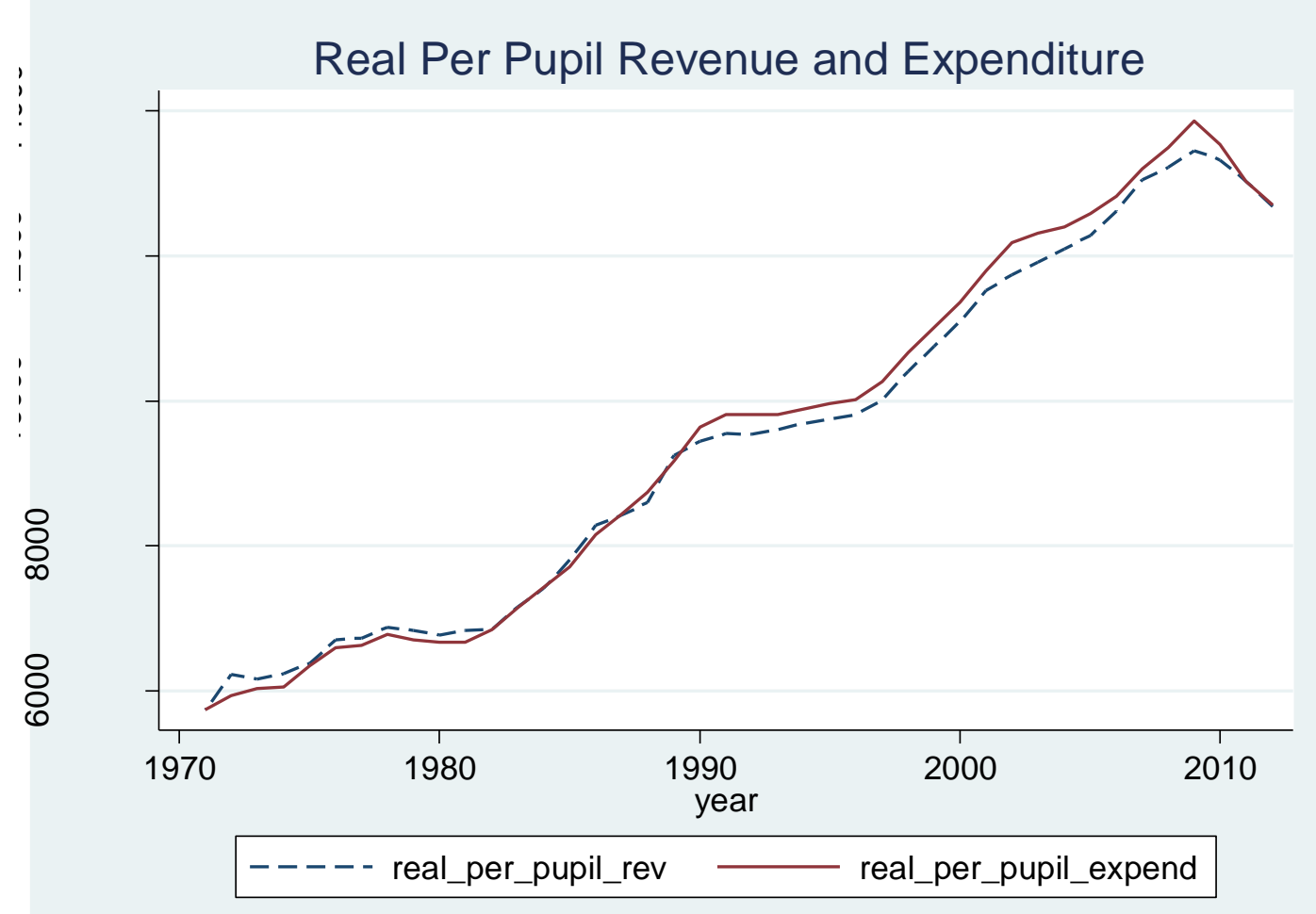

Figure 4 shows the graph of per pupil education revenue by the source of that revenue.

The dashed (blue) line is state revenue, the higher solid (red) line is local revenue, and the lower solid (green) line is federal revenue. Both state and local revenue generally show a similar pattern to that of total revenue; strong upward trends until the years of the recent recession. Federal revenue shows a much more modest increase, though this picked up in the early 2000s. In the later 2000s, there was a sharp increase in the aftermath of the recession, then a decline.

Figure 5 displays some components of total expenditures. The dashed (blue) is the time path of current expenditures (all expenditures less capital expenses). The solid (red) line is instructional expenditure, available only since 1986 . These both show a pattern very similar to 


\section{Figure 4}

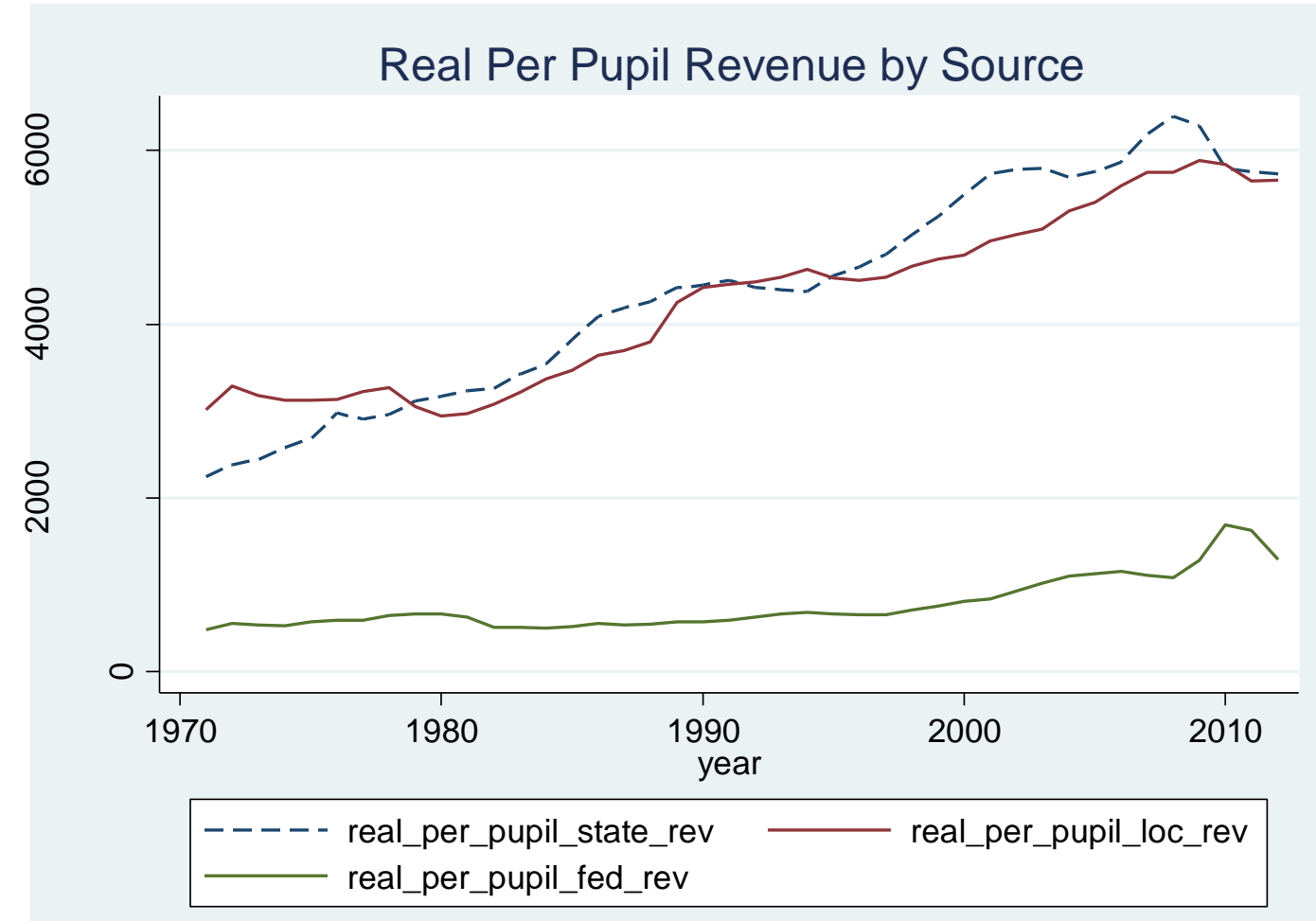

that of total expenditures; rising substantially throughout this time period except for the period immediately following the recent recession.

The next set of figures (6 and 7) examine and update the trend in the productivity of educational funding. This is computed as the NAEP test score per $\$ 1,000$ of educational revenue. This can be thought as the effectiveness of education dollars in producing educational outcomes. We compute this ratio for each of the four NAEP tests we are considering. These productivity data are reported in appendix table A3. Figure 6 shows the plot over time for grades 4 and 8 reading scores. 


\section{Figure 5}

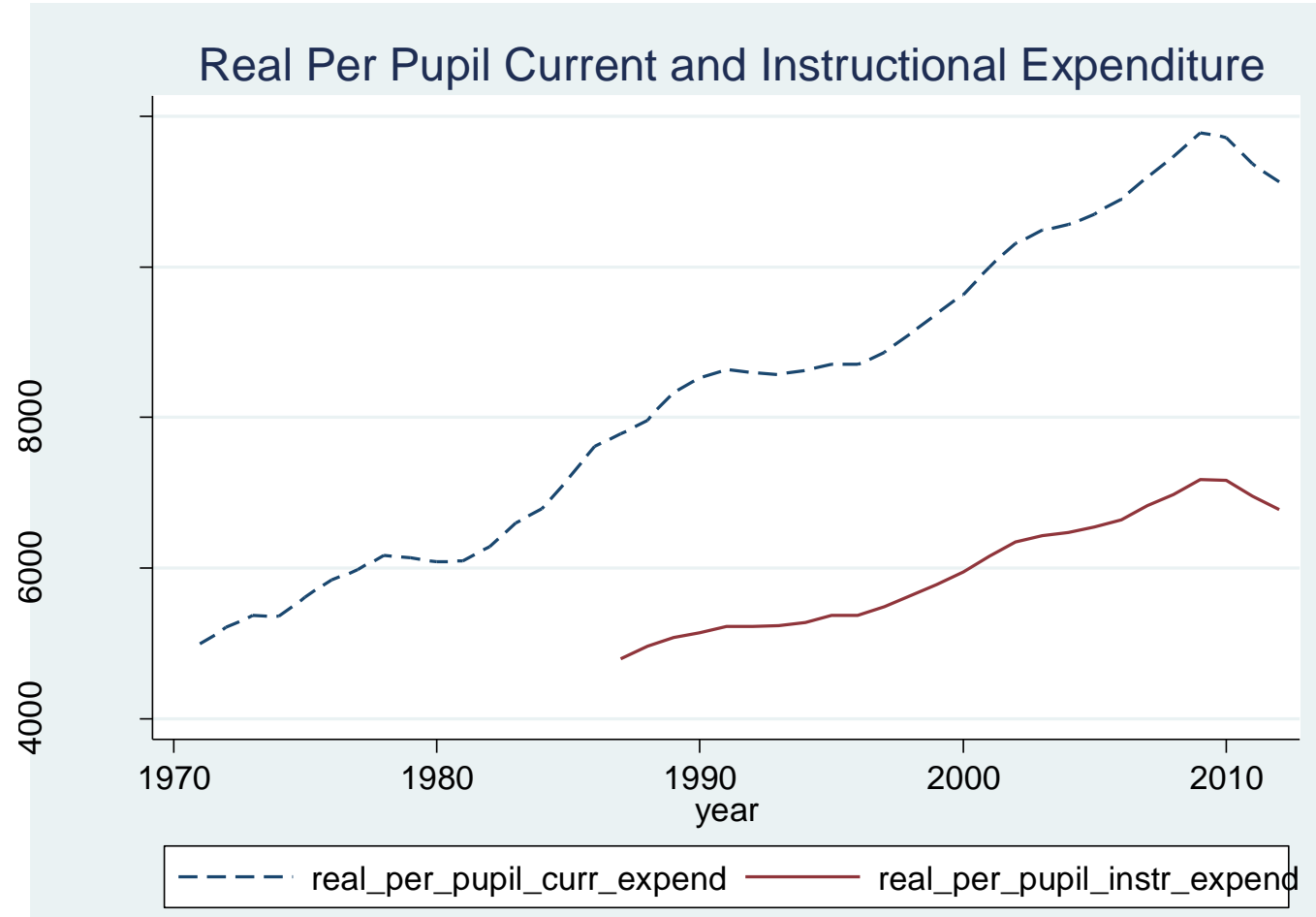

Figure 6

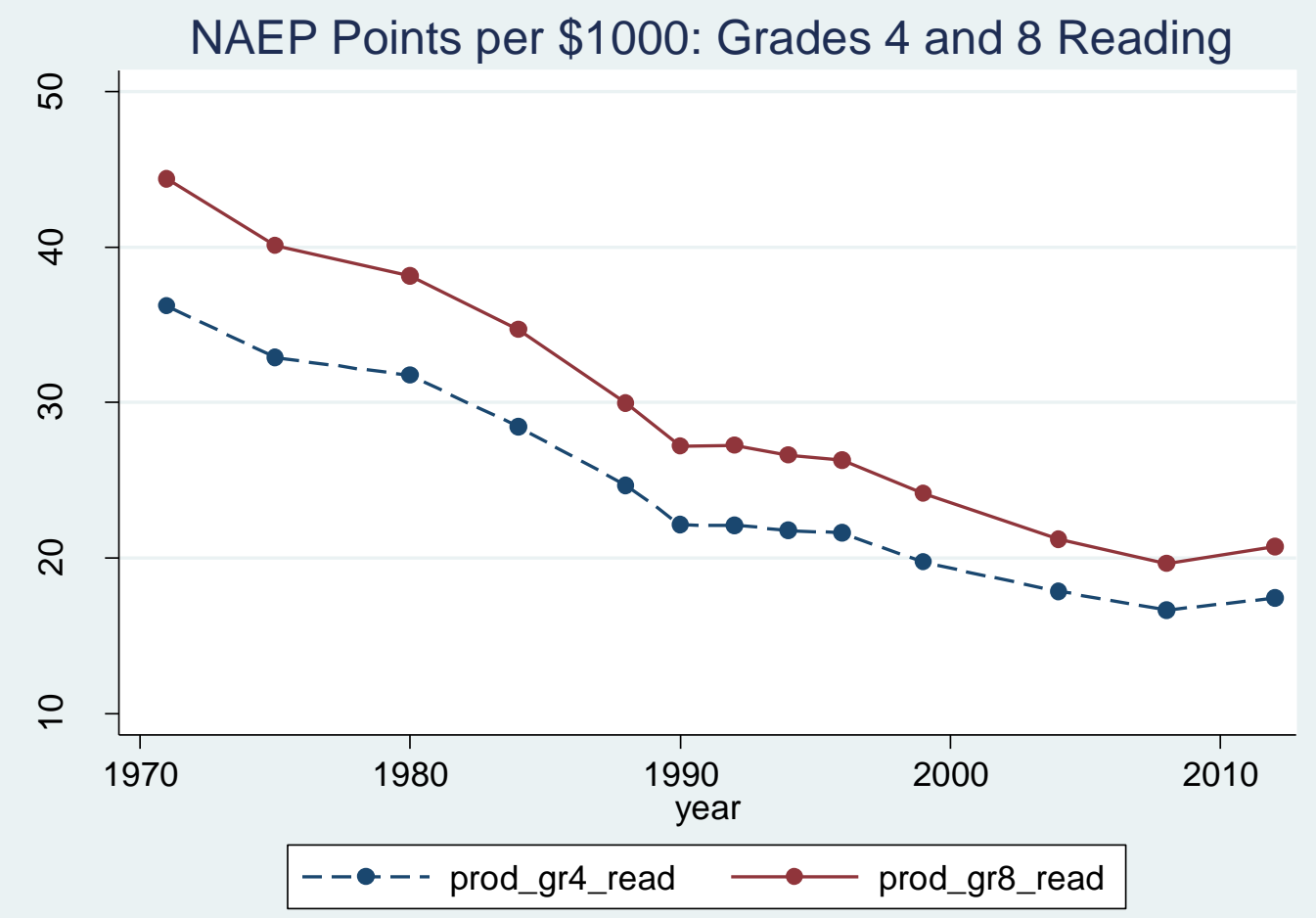


The dashed (blue) line in Figure 6 is for grade 4 and the solid (red) line is for grade 8. Both display an essentially continuous downward trend for the entire time period. The exception is the last two years of tests that show an uptick. This is largely due to the post-recession decline in education spending. From 2008 to 2012, education revenue per pupil fell by 4\%. However, grade 4 reading scores increased by $1 / 2$ of $1 \%$ and grade 8 reading scores rose by $1 \%$. Thus, most of the increased productivity in this time frame was due to declining funding.

Figure 7 shows the plot of productivity for grade 4 and grade 8 math. There is a general similarity to the reading score plot; an overall and mostly continuous downward trend. Here, there is an exception between the 1978 and 1982 tests, as well as for the final 2008 to 2012 period.

\section{Figure 7}

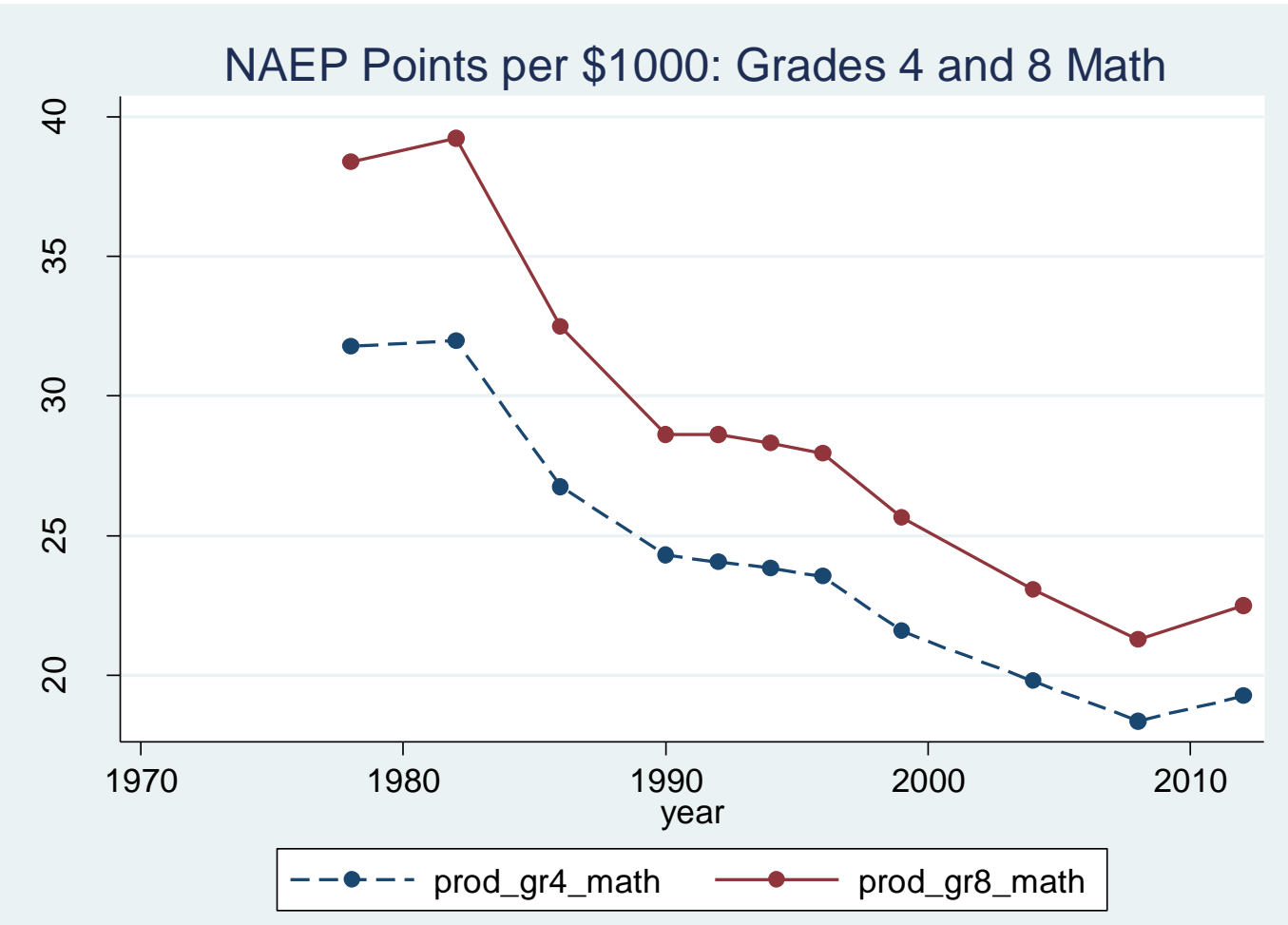


Visually, the rates of decline seem sharpest prior to 1990, followed by smaller declines in the 1990s, then further declines in the 2000s that are not as large as in the earliest period. This is verified in Table 1 below. We show the annual average decline in productivity for each test for three time periods: 1990 and before, 1990 to 1999, and 1999 and after. For the last period, we consider both the 1999 - 2008 period and the 1999 - 2012 period, where the former excludes the effect of the last recession.

Table 1 verifies the visual analysis. Up through 1990, the annual average absolute decline in productivity for each test ranges from 0.62 points per year to 0.90 . The percent decline is about $2 \%$ per year for each test. During the 1990 s, the decline in productivity continued, but at a slower rate. For each test, the absolute decline was roughly 0.30 points per year, or a little over $1 \%$ reduced productivity per year. From 1999 to 2008, productivity fell faster than in the 1990s, but slower than the earlier period. Declines in lost points per year ranged from 0.34 to 0.5 , translating into percentage reductions between $1.6 \%$ and $2.0 \%$. With the time period 1999 to 2012, absolute and percentage reductions are the smallest due to the 2008 to 2012 uptick. Note, though, in none of these time periods did productivity rise. The differences are how quickly it declines.

Figures 8 and 9 plot the productivity for all students (as in previous figures), along with the productivity for black student scores, i.e., the average NAEP score for black students per $\$ 1,000$ of educational revenue. This addresses the issue of whether the additional funding for schools over this time period was targeted toward minorities in order to raise their scores and educational outcomes, and thereby reduce racial inequality. If this were the case, we expect to see higher black student test scores per $\$ 1,000$ of spending relative to all students. 
Table 1

\begin{tabular}{|l|c|c|c|c|c|c|c|c|}
\hline \multicolumn{8}{|c|}{ Annual Average Absolute and Percent Decline in Productivity (NAEP Score per } \\
$\$ 1000$ ): Grades 4 and 8 Reading and Math \\
\hline & Grade 4 Reading & \multicolumn{2}{c|}{ Grade 8 Reading } & \multicolumn{2}{c|}{ Grade 4 Math } & \multicolumn{2}{c|}{ Grade 8 Math } \\
\hline & $\begin{array}{l}\text { Absolute } \\
\text { Annual } \\
\text { Prod. } \\
\text { Decline }\end{array}$ & $\begin{array}{l}\text { Percent } \\
\text { Annual } \\
\text { Prod. } \\
\text { Decline }\end{array}$ & $\begin{array}{l}\text { Absolute } \\
\text { Annual } \\
\text { Prod. } \\
\text { Decline }\end{array}$ & $\begin{array}{l}\text { Percent } \\
\text { Annual } \\
\text { Prod. } \\
\text { Decline }\end{array}$ & $\begin{array}{l}\text { Absolute } \\
\text { Annual } \\
\text { Prod. } \\
\text { Decline }\end{array}$ & $\begin{array}{l}\text { Percent } \\
\text { Annual } \\
\text { Prod. } \\
\text { Decline }\end{array}$ & $\begin{array}{l}\text { Absolute } \\
\text { Annual } \\
\text { Prod. } \\
\text { Decline }\end{array}$ & $\begin{array}{l}\text { Percent } \\
\text { Annual } \\
\text { Prod. } \\
\text { Decline }\end{array}$ \\
\hline $\begin{array}{l}1990 \\
\text { and } \\
\text { before }\end{array}$ & 0.74 & $2.1 \%$ & 0.90 & $2.0 \%$ & 0.62 & $2.0 \%$ & 0.82 & $2.1 \%$ \\
\hline $\begin{array}{l}1990 \text { to } \\
1999\end{array}$ & 0.27 & $1.2 \%$ & 0.34 & $1.3 \%$ & 0.30 & $1.2 \%$ & 0.32 & $1.1 \%$ \\
\hline $\begin{array}{l}1999 \text { to } \\
2008\end{array}$ & 0.34 & $1.7 \%$ & 0.5 & $2.0 \%$ & 0.35 & $1.6 \%$ & 0.49 & $1.9 \%$ \\
\hline $\begin{array}{l}1999 \text { to } \\
2012\end{array}$ & 0.18 & $0.9 \%$ & 0.26 & $1.1 \%$ & 0.18 & $0.95 \%$ & 0.24 & $1.0 \%$ \\
\hline
\end{tabular}

\section{Figure 8}

NAEP Points per \$1000: Grade 4 Reading for All and Black

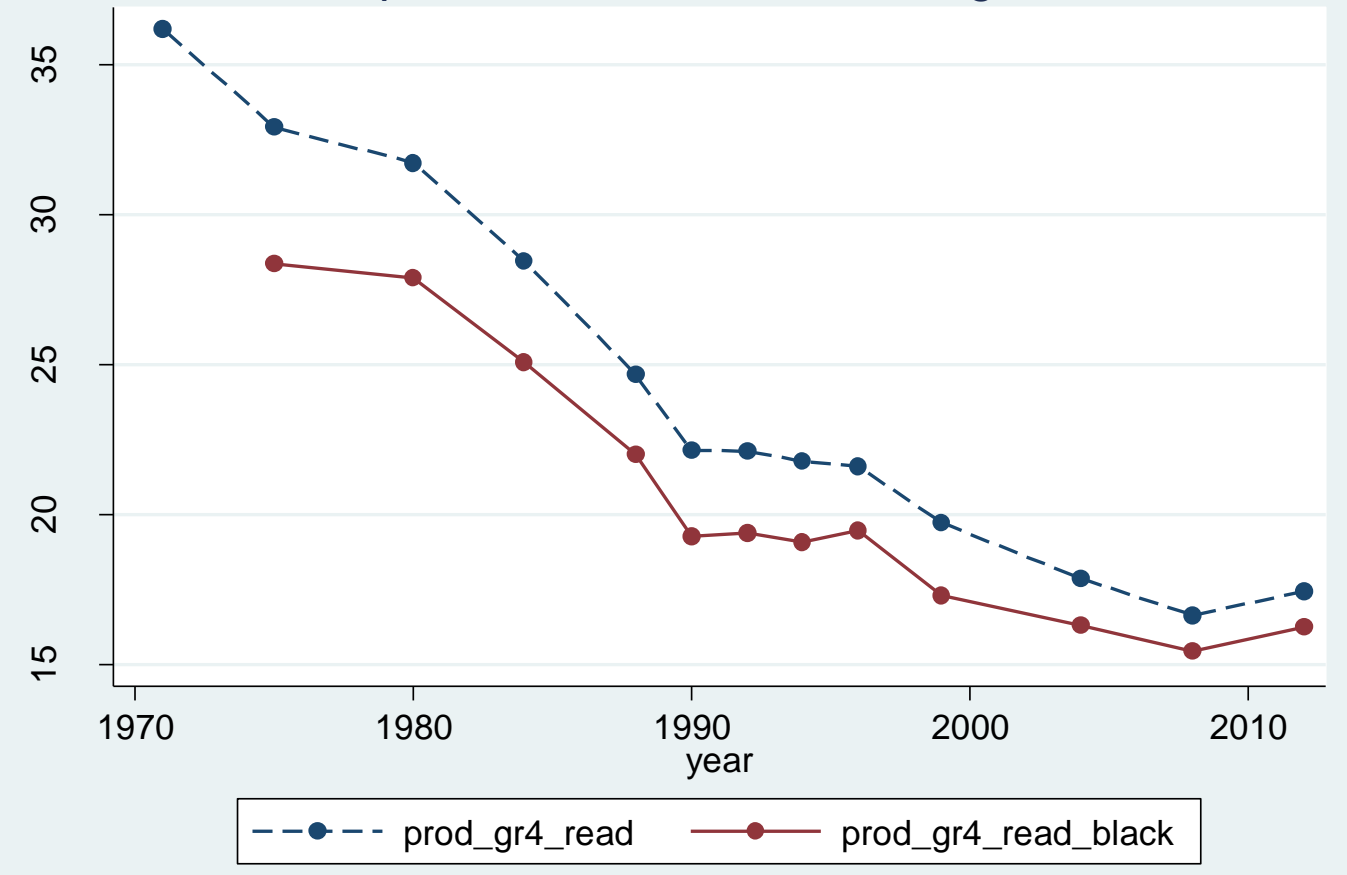


Figures 8 and 9 show that this did not occur. Figure 8 is for grade 4 reading and Figure 9 is for grade 8 reading. In both figures, the dashed (blue) line represents all students and the solid (red) line for black students. The trend in productivity for the two groups track one another almost exactly. Black student productivity outcomes show the same pattern of decline as all students. Repeating this exercise for math scores yields the same outcome.

\section{Figure 9}

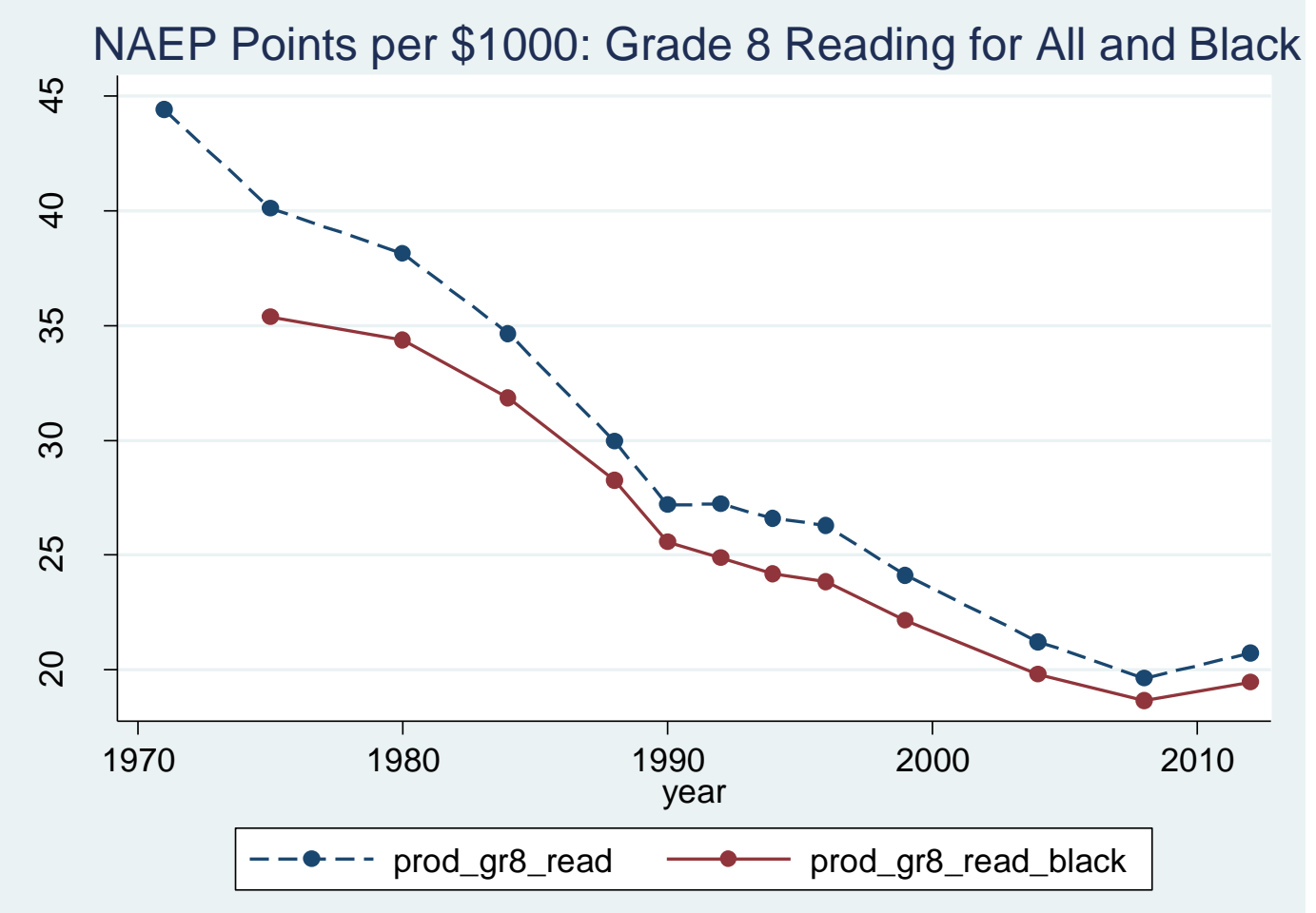

Overall, the findings for nationwide trends are not that different from Hoxby's (2004), even with consideration of the last decade of data. Test scores do show some improvement over the 2000s, but education spending increased rapidly until the last recession. The productivity of educational funds continues to decline, albeit not as rapidly as in the 1970s and 1980s. The pattern for productivity is the same for black students as all students. 


\section{Spending and Test Scores Across States and Over Time}

This section utilizes the state-level NAEP test score data and state-level educational funding to examine the relationship between school spending and test scores, as well as the productivity of school spending. An advantage of these data is that states have varying experiences regarding changes in funding and test score outcomes over time, and states naturally vary in these respects at any point in time. There is much greater variation in the relevant data than in the national data, and so ought to be more informative in assessing the association of spending and test scores. We also consider the effects of spending on black student scores, examine if there are differences based on whether the source of funds is federal, state, or local, and reexamine the productivity of education funding with the cross-state panel.

\section{A. Summary Statistics and Econometric Specification}

Appendix Table A4 shows the years the state-based NAEP tests were given. The first began in 1990 and they were given at various times to most, though not all, states. Since 2003, the assessments that we use have been given every two years to all states.

The basic methodology used is regression analysis of the form in equation (1).

$$
\mathrm{T}_{\mathrm{jt}}=\mathrm{b}_{0}+\mathrm{b}_{1} \mathrm{~S}_{\mathrm{jt}}+\mathrm{b}_{2} \mathrm{X}_{\mathrm{jt}}+\theta_{\mathrm{j}}+\delta_{\mathrm{t}}+\varepsilon_{\mathrm{jt}}
$$

where $\mathrm{j}$ indexes states, $\mathrm{t}$ indexes time and:

$\mathrm{T}_{\mathrm{jt}}=$ state $\mathrm{j}$ 's average test score at time $\mathrm{t}$ (where we estimate separate equations for each test),

$\mathrm{S}_{\mathrm{jt}}=$ state $\mathrm{j}$ 's real per pupil funding at time $\mathrm{t}$,

$\mathrm{X}_{\mathrm{jt}}=\mathrm{a}$ vector of demographics for state $\mathrm{j}$ at time $\mathrm{t}$,

$\theta_{\mathrm{j}}=\mathrm{a}$ vector of state effect dummy variables,

$\delta_{\mathrm{t}}=\mathrm{a}$ vector of year effect dummy variables, and

$\varepsilon_{\mathrm{jt}}=$ white noise 
We adopt and report a number of specifications that utilize different subsets of the above variables. The full specification allows for the influence of state spending on test scores, with controls for differences and changes in state demographics, state-specific influences, and timedependent effects.

Table 2 presents means and standard deviations, as well as variable definitions, for the test score, funding, and demographic variables. The columns show these summary statistics for each test, with the data pooled across states and over time. Prior to 2003, different tests were given at different intervals, so sample sizes are not the same for each test. Also, the primary variable we use for school funding is real revenue per pupil, lagged one year. The mean for this variable in each column is approximately $\$ 12,000$ per pupil in 2016 dollars. ${ }^{3}$ We use funding with a one-year lag largely because the last year of test score data is 2015 and the last year of funding data is 2014. Thus, using lagged funding enables us to use the 2015 test score data. However, dropping 2015 or using different lag lengths do not substantially change our findings. The demographics we use include the racial composition of the state's public school students, the percent of the state's students eligible for the federal reduced price lunch program, the percent of students identified as English language learners, and the percent of students with disability. States have some latitude in whether English language learners and students with disability are tested, so we include the percent of each that were assessed. After 1998, states were enabled to test these two groups with accommodation, and we include the percent who were assessed with accommodation.

\footnotetext{
${ }^{3}$ We also experimented using expenditures instead of revenue but with essentially identical findings.
} 
Table 2: Means (standard deviations), State Level NAEP Scores, Educational Revenue, and Demographics

\begin{tabular}{|c|c|c|c|c|}
\hline Variable $^{\mathrm{a}}$ & $\begin{array}{l}\text { Grade } 4 \\
\text { Reading } \\
\end{array}$ & $\begin{array}{l}\text { Grade } 8 \\
\text { Reading } \\
\end{array}$ & $\begin{array}{c}\text { Grade } 4 \\
\text { Math }\end{array}$ & $\begin{array}{l}\text { Grade } 8 \\
\text { Math }\end{array}$ \\
\hline NAEP State Score & $\begin{array}{r}218.29 \\
(8.03)\end{array}$ & $\begin{array}{l}263.23 \\
(6.76)\end{array}$ & $\begin{array}{l}234.25 \\
(10.56)\end{array}$ & $\begin{array}{l}276.87 \\
(11.07)\end{array}$ \\
\hline $\begin{array}{l}\text { Real revenue per pupil } \\
\text { (lagged one year) }\end{array}$ & $\begin{array}{l}12023.81 \\
(3422.29)\end{array}$ & $\begin{array}{l}12530.18 \\
(3389.74)\end{array}$ & $\begin{array}{l}12163.85 \\
(3432.21)\end{array}$ & $\begin{array}{l}11956.71 \\
(3439.64)\end{array}$ \\
\hline Percent White students & $\begin{array}{c}65.05 \\
(20.22)\end{array}$ & $\begin{array}{c}64.74 \\
(20.23)\end{array}$ & $\begin{array}{c}63.69 \\
(19.87)\end{array}$ & $\begin{array}{c}66.61 \\
(20.64)\end{array}$ \\
\hline Percent Black students & $\begin{array}{c}15.73 \\
(16.16)\end{array}$ & $\begin{array}{c}15.43 \\
(16.05)\end{array}$ & $\begin{array}{c}15.32 \\
(15.77)\end{array}$ & $\begin{array}{c}15.23 \\
(16.33)\end{array}$ \\
\hline Percent Hispanic students & $\begin{array}{c}11.64 \\
(13.54)\end{array}$ & $\begin{array}{c}11.57 \\
(12.79)\end{array}$ & $\begin{array}{c}12.99 \\
(12.97)\end{array}$ & $\begin{array}{c}10.69 \\
(12.55)\end{array}$ \\
\hline $\begin{array}{l}\text { Percent Reduced Price } \\
\text { School Lunch Eligible }\end{array}$ & $\begin{array}{c}41.89 \\
(13.78)\end{array}$ & $\begin{array}{c}42.95 \\
(11.47)\end{array}$ & $\begin{array}{c}43.22 \\
(13.55)\end{array}$ & $\begin{array}{c}39.41 \\
(13.42)\end{array}$ \\
\hline $\begin{array}{l}\text { Pct. Students English } \\
\text { Language Learners }\end{array}$ & $\begin{array}{c}7.66 \\
(7.38)\end{array}$ & $\begin{array}{c}5.74 \\
(5.59)\end{array}$ & $\begin{array}{c}6.27 \\
(6.02)\end{array}$ & $\begin{array}{c}3.70 \\
(3.64)\end{array}$ \\
\hline $\begin{array}{l}\text { Pct. of English Language } \\
\text { Learners assessed }\end{array}$ & $\begin{array}{l}5.99 \\
(6.59)\end{array}$ & $\begin{array}{l}4.60 \\
(5.07)\end{array}$ & $\begin{array}{c}5.52 \\
(5.68)\end{array}$ & $\begin{array}{c}3.12 \\
(3.39)\end{array}$ \\
\hline $\begin{array}{l}\text { Pct. of English Language } \\
\text { Learners tested with } \\
\text { accommodation }\end{array}$ & $\begin{array}{c}2.69 \\
(4.08)\end{array}$ & $\begin{array}{l}2.26 \\
(3.73)\end{array}$ & $\begin{array}{c}2.56 \\
(2.74)\end{array}$ & $\begin{array}{l}1.28 \\
(1.45)\end{array}$ \\
\hline $\begin{array}{l}\text { Pct. of Students with } \\
\text { Disability }\end{array}$ & $\begin{array}{l}13.59 \\
(2.89)\end{array}$ & $\begin{array}{l}13.49 \\
(2.50)\end{array}$ & $\begin{array}{l}13.58 \\
(2.89)\end{array}$ & $\begin{array}{l}12.55 \\
(2.90)\end{array}$ \\
\hline $\begin{array}{l}\text { Pct. of Students with } \\
\text { Disability assessed }\end{array}$ & $\begin{array}{c}9.50 \\
(3.56)\end{array}$ & $\begin{array}{l}10.09 \\
(2.89)\end{array}$ & $\begin{array}{l}10.91 \\
(3.63)\end{array}$ & $\begin{array}{c}9.50 \\
(3.63)\end{array}$ \\
\hline $\begin{array}{l}\text { Pct. of Students with } \\
\text { Disability tested with } \\
\text { accommodation }\end{array}$ & $\begin{array}{c}5.64 \\
(4.09)\end{array}$ & $\begin{array}{c}6.92 \\
(3.62)\end{array}$ & $\begin{array}{c}7.16 \\
(4.34)\end{array}$ & $\begin{array}{c}6.20 \\
(4.50)\end{array}$ \\
\hline $\mathrm{N}$ (sample size) & 523 & 436 & 484 & 517 \\
\hline
\end{tabular}

${ }^{\mathrm{a} A l l}$ variables are statewide averages for each sample year.

\section{B. Basic Findings}

Naturally, we are most interested in the coefficient $b_{2}$, showing the relationship of state funding to test scores. Table 3 shows the findings of four different specifications for the grade 4 
reading exam. The coefficient on funding is transformed to indicate the influence of $\$ 1,000$ of per pupil funding. The full set of coefficients is in appendix Table A5. Column (1) shows the

Table 3: Coefficient Estimates, Grade 4 Reading Equation

Dependent Variable: NAEP Grade 4 Reading Score (absolute value of $t$-statistics in parentheses)

\begin{tabular}{|l|c|c|c|c|}
\hline Variable & $\underline{(1)}$ & $\underline{(2)}$ & $\underline{(3)}$ & $\underline{(4)}$ \\
\hline Real revenue per pupil, & .6119 & .2567 & .6992 & .2549 \\
lagged one year $(\$ 1,000)$ & $(6.16)$ & $(2.94)$ & $(6.51)$ & $(2.18)$ \\
\hline Demographics & no & yes & yes & yes \\
\hline State effects & no & no & yes & yes \\
\hline Year effects & no & no & no & yes \\
\hline $\mathrm{R}^{2}$ & 0.0680 & 0.6432 & 0.8853 & 0.9108 \\
\hline $\mathrm{N}$ & 523 & 523 & 523 & 523 \\
\hline
\end{tabular}

results of a univariate regression of the test score on funding, with no control variables. The coefficient of .6119 indicates that a $\$ 1,000$ increase in per pupil funding is associated with a little over a 0.6 point rise in the grade 4 NAEP reading score. Column (2) adds controls for the demographic variables since a state's average score may be influenced by its demographic composition. With this specification, the coefficient on funding falls to .2567 , implying that additional funding of $\$ 1,000$ per student is associated with just over a $1 / 4$ point higher test score.

Because there are likely to be many difference across states not fully captured by the demographic variation, column (3) adds state fixed effects to account for them. Doing so allows for different "baseline" levels for each state and so our results reflect the effects of within-state changes over time. In this specification, the coefficient on funding is .6992 , indicating that a $\$ 1,000$ increase in funding by a state is associated with an almost 0.7 point higher test score. Lastly, column (4) adds time effect dummy variables. This allows for nationwide trends from other, unmeasured sources to affect test scores and is the standard difference-in-differences 
specification (with covariates), and is our preferred specification. The results here reflect the effects of within-state changes in funding relative to other states as a whole. Here, the coefficient on funding is .2549 , implying that a $\$ 1,000$ increase in funding is associated with a little over a $1 / 4$ point increase in the test score. ${ }^{4}$

Care must be taken in interpreting these coefficients as causal. Clearly, funding is endogenous to policy makers, and if unobservables drive both funding and test scores, the associations we find may not be causal. However, the state and time effects may account for many of these unobservable factors.

Note that all of the estimated effects of funding have a high degree of statistical significance. However, the magnitudes of the effects are very small. Focus on the estimates in columns (3) and (4). These, we believe, are the most meaningful. Recall that the column (4) specification accounts for demographics, state effects, and time effects, and shows the effect of changes in state funding relative to the nation. Column (3) does not include the time effects, so the influence of unobserved, national trends may be attributed to the effect of funding. Thus, the column (3) result is probably an upper-bound estimate of the influence of funding.

Though the estimate of column (3) is over twice as large at that in column (4) - .6992 compared to .2549 - both are small in magnitude. A $\$ 1,000$ increase in per pupil funding is associated with 0.7 test points for the former and $1 / 4$ point for the latter. The yearly average for this test score is about 218 , and the yearly standard deviation varies over time but ranges from about 6 to almost 10 . Thus, $\$ 1,000$ "buys" only a very minimal change in the test score with either estimate. Note that $\$ 1,000$ is a substantial share of per pupil spending. From Table 2, the

\footnotetext{
${ }^{4}$ Though column (4) is our preferred specification, we report other specifications so the reader may gain a fuller picture of the findings.
} 
average of per pupil spending is about $\$ 12,000$ per year. An increment of $\$ 1,000$ is an $8.3 \%$ change.

The theme from Table 3 recurs with the other tests: effects that are statistically significant but very small in magnitude. This is evident from Table 4, which shows the findings for the grade 8 reading test. The full set of coefficients is in appendix Table A6. Column (1) estimates the effect of $\$ 1,000$ more in funding at .30 point, column (2) indicates .11 points, column (3) about .25 points, and column (4) .20 points. Each is statistically significant except for the coefficient in column (2). Regarding our preferred specifications of column (4) and the upper-bound estimate of column (3), their magnitudes are not that different and both are very small. Yearly standard deviations for this test range between 6 and 7 . Thus, a .20 or .25 change in the test score is quite minimal.

Table 4: Coefficient Estimates, Grade 8 Reading Equation Dependent Variable: NAEP Grade 8 Reading Score (absolute value of $t$-statistics in parentheses)

\begin{tabular}{|l|c|c|c|c|}
\hline Variable & $\underline{(1)}$ & $\underline{(2)}$ & $\underline{(3)}$ & $\underline{(4)}$ \\
\hline Real revenue per pupil, & .3064 & .1131 & .2478 & .2033 \\
lagged one year $(\$ 1,000)$ & $(3.24)$ & $(1.57)$ & $(3.09)$ & $(2.35)$ \\
\hline Demographics & no & yes & yes & yes \\
\hline State effects & no & no & yes & yes \\
\hline Year effects & no & no & no & yes \\
\hline $\mathrm{R}^{2}$ & 0.0236 & 0.7636 & 0.9366 & 0.9499 \\
\hline $\mathrm{N}$ & 436 & 436 & 436 & 436 \\
\hline
\end{tabular}

Table 5 presents the findings for grade 4 math NAEP test scores, with full results in appendix Table A7. Focus again on columns (3) and (4). The column (3) estimate indicates a gain of 1.22 points per $\$ 1,000$ of funding, while that in column (4) shows 0.29 points. The average score for this test is around 234, and yearly standard deviation ranges from 5 to 8.5 . 
Though the column (3) estimate is larger than that for the reading score, its magnitude is still not that large. The magnitude of the column (4) estimate is small as previously.

Table 5: Coefficient Estimates, Grade 4 Math Equation*

Dependent Variable: NAEP Grade 4 Math Score (absolute value of $t$-statistics in parentheses)

\begin{tabular}{|l|c|c|c|c|}
\hline Variable & $\underline{(1)}$ & $\underline{(2)}$ & $\underline{(3)}$ & $\underline{(4)}$ \\
\hline Real revenue per pupil, & 1.2101 & .2094 & 1.2159 & .2902 \\
lagged one year $(\$ 1,000)$ & $(9.39)$ & $(1.97)$ & $(8.14)$ & $(2.55)$ \\
\hline Demographics & no & yes & yes & yes \\
\hline State effects & no & no & yes & yes \\
\hline Year effects & no & no & no & yes \\
\hline $\mathrm{R}^{2}$ & 0.1546 & 0.6981 & 0.8916 & 0.9538 \\
\hline $\mathrm{N}$ & 484 & 484 & 484 & 484 \\
\hline
\end{tabular}

Lastly, Table 6 presents the findings for grade 8 math scores, with full results in appendix Table A8. Regarding the coefficients in columns (3) and (4), the former indicates a gain of 1.39 points per $\$ 1,000$ of funding, while that in column (4) shows 0.52 points. Given an average test score of around 234 and a yearly standard deviation that ranges from 7 to 11 , the magnitude of either of these estimates is not especially large.

Table 6: Coefficient Estimates, Grade 8 Math Equation

Dependent Variable: NAEP Grade 8 Math Score (absolute value of t-statistics in parentheses)

\begin{tabular}{|l|c|c|c|c|}
\hline Variable & $\underline{(1)}$ & $\underline{(2)}$ & $\underline{(3)}$ & $\underline{(4)}$ \\
\hline Real revenue per pupil, & 1.1562 & .437 & 1.3896 & .5193 \\
lagged one year $(\$ 1,000)$ & $(8.74)$ & $(3.41)$ & $(10.78)$ & $(4.00)$ \\
\hline Demographics & no & yes & yes & yes \\
\hline State effects & no & no & yes & yes \\
\hline Year effects & no & no & no & yes \\
\hline $\mathrm{R}^{2}$ & 0.1291 & 0.6638 & 0.9171 & 0.9443 \\
\hline $\mathrm{N}$ & 517 & 517 & 517 & 517 \\
\hline
\end{tabular}


Table 7 summarizes the association of per pupil spending with test scores for each of the NAEP tests. The first row of this table recaps the findings presented in Tables 3 through 6 . In particular, we show the effect of a $\$ 1,000$ increase in per pupil funding based on the column (3) and the column (4) estimates. The estimates without year effects are larger, though, as noted above, these are upper-bound estimates. Also as noted, these effects are small in magnitude.

The second row of Table 7 presents another way to illustrate the magnitude of the effects. Based on the coefficient estimates, we calculate the additional funding needed to move each test score by one-half of a standard deviation. With such a change, a state at the $33^{\text {rd }}$ percentile of scores would move to the median, or a state at the median would move to the $66^{\text {th }}$ percentile. Because the standard deviation of test scores varies from year to year, we use its average over time for each test.

As can be seen, these dollar values are quite large. For grade 4 reading and the column (1) value, the additional required funds is $\$ 5,422$. Using the column (2) value, it is even larger at $\$ 14,863$. Note that the mean state per pupil funding (from Table 2) is about $\$ 12,000$ and for 2014 it is $\$ 13,362$. Thus, either of our computations imply a massive funding increase to attain such a score change: a 40\% rise with the column (1) computation - based on 2015 mean spending - and an over $100 \%$ increase with column (2). Of course, these large values stem entirely from the small values of the coefficient estimates.

Regarding grade 8 reading, both computations indicate over a $100 \%$ rise in funding to attain the one-half standard deviation score increase. For the grade 4 and grade 8 math scores, a somewhat different picture emerges. Referring to columns (5) and (7), the necessary funding increase is $\$ 2,788$ for grade 4 and $\$ 3,209$ for grade 8 . These translate into $21 \%$ and $24 \%$ funding increases, respectively. The computations from columns (6) and (8), though, show much larger 
values. For the grade 4 math computation in column (6), the funding increase needed is $87 \%$ and for grade 8 math in column (8) it is $63 \%$.

Table 7: Summary Estimates: The Association of Per Pupil Funding to Test Scores

\begin{tabular}{|l|c|c|c|c|c|c|c|c|}
\hline & \multicolumn{2}{|c|}{ Grade 4 Reading } & \multicolumn{2}{c|}{ Grade 8 Reading } & \multicolumn{2}{c|}{ Grade 4 Math } & \multicolumn{2}{c|}{ Grade 8 Math } \\
\hline & $(1)^{\mathrm{a}}$ & $(2)^{\mathrm{b}}$ & $(3)^{\mathrm{a}}$ & $(4)^{\mathrm{b}}$ & $(5)^{\mathrm{a}}$ & $(6)^{\mathrm{b}}$ & $(7)^{\mathrm{a}}$ & $(8)^{\mathrm{b}}$ \\
\hline $\begin{array}{l}\text { Points from } \\
\$ 1 \mathrm{~K} \text { of funds }\end{array}$ & .699 & .255 & .248 & .203 & 1.216 & .290 & 1.390 & .529 \\
\hline $\begin{array}{l}\text { Funding for a } \\
1 / 2 \sigma \text { score } \\
\text { change }^{\mathrm{c}}\end{array}$ & $\$ 5,422$ & $\$ 14,863$ & $\$ 13,327$ & $\$ 16,281$ & $\$ 2,788$ & $\$ 11,690$ & $\$ 3,209$ & $\$ 8,431$ \\
\hline
\end{tabular}

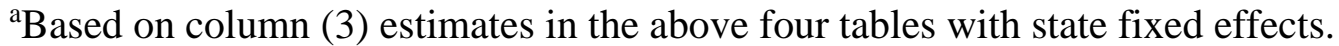

${ }^{b}$ Based on column (4) estimates in the above four tables with state and year fixed effects.

${ }^{\mathrm{c}}$ Yearly standard deviations of test scores vary. We use the average yearly standard deviation for each test. One-half of these are 3.79 for grade 4 reading, 3.305 for grade 8 reading, 3.39 for grade 4 math, and 4.46 for grade 8 math.

\section{Findings for Black Student Scores}

We consider if the influence of funding has a different effect on average black student scores than on the average of all students. If the effect on black student scores is substantially larger, then the funding tends to reduce racial inequality in scores.

Table 8 shows the findings for both grade 4 and 8 reading scores, where the dependent variable is the state's average NAEP score for black students. We report on the specification with just state effects and also that with both state and year effects. Overall the findings are similar to above in that the estimates with state effects only are larger, but the magnitude of the effects are quite small. The effect of funding on black student scores is somewhat larger for some of the specification, though not for all. ${ }^{5}$

\footnotetext{
${ }^{5}$ The sample sizes for the black student results are smaller because not all states report black student scores for all years. When we estimate using the same sample of states, comparable findings appear.
} 
Table 8: Coefficient Estimates, Grade 4 and 8 Reading, Black Students

Dependent Variable: NAEP Reading Score, Black Students (absolute value of $t$-statistics in parentheses)

\begin{tabular}{|l|c|c|c|c|}
\hline \multicolumn{1}{|c|}{} & \multicolumn{2}{|c|}{ Grade 4 } & \multicolumn{2}{c|}{ Grade 8 } \\
\hline Variable & $\underline{(1)}$ & $\underline{(2)}$ & $\underline{(3)}$ & $\underline{(4)}$ \\
\hline Real revenue per pupil, & .9114 & .0645 & .5788 & .3445 \\
\hline lagged one year (\$1,000) & $(4.73)$ & $(0.32)$ & $(3.84)$ & $(2.00)$ \\
\hline Demographics & yes & yes & yes & yes \\
\hline State effects & yes & yes & yes & yes \\
\hline Year effects & no & yes & no & yes \\
\hline $\mathrm{R}^{2}$ & .7405 & .8172 & .7712 & .7982 \\
\hline $\mathrm{N}$ & 447 & 447 & 359 & 359 \\
\hline
\end{tabular}

Table 9 presents the results for grade 4 and grade 8 math scores for black students, organized as in Table 8 . Very similar comments apply as with the reading scores. Even though a number of the coefficients are larger for black student scores, the small magnitudes imply that

Table 9: Coefficient Estimates, Grade 4 and 8 Math, Black Students

Dependent Variable: NAEP Math Score, Black Students (absolute value of $t$-statistics in parentheses)

\begin{tabular}{|l|c|c|c|c|}
\hline \multicolumn{1}{|c|}{} & \multicolumn{2}{|c|}{ Grade 4 } & \multicolumn{2}{c|}{ Grade 8 } \\
\hline Variable & $\underline{(1)}$ & $\underline{(2)}$ & $\underline{(3)}$ & $\underline{(4)}$ \\
\hline Real revenue per pupil, & 1.3818 & .0927 & 1.8914 & .7355 \\
lagged one year (\$1,000) & $(6.44)$ & $(0.53)$ & $(9.31)$ & $(3.40)$ \\
\hline Demographics & yes & yes & yes & yes \\
\hline State effects & yes & yes & yes & yes \\
\hline Year effects & no & yes & no & yes \\
\hline $\mathrm{R}^{2}$ & .8633 & .9326 & .8536 & .8920 \\
\hline $\mathrm{N}$ & 411 & 411 & 416 & 416 \\
\hline
\end{tabular}

there is very little effect on score inequality. For example, if the effect on black students is 0.50 higher than on all students (the largest of the different effects that we find), a $\$ 1,000$ increase in funding raises black student scores by a half point more that all students. The differential 
between the average score of black students and all of students varies across the tests, but is at least 16 points (the black-white differential is larger). Thus, such a change implies a very minimal effect on score inequality

\section{Effects by Source of Funds}

Funds for public schools may come from three sources: the federal government, state government, or local government. ${ }^{6}$ Because funds from different levels of government may be earmarked for certain uses and have various restrictions and rules on their use, the effectiveness may differ by fund source. Thus, we re-estimate our test score equations by replacing the total per pupil funding with three variables: federal, state, and local per pupil funding. Tables 10 and 11 present the findings. We show only two specifications; that with state effects and that with state and year effects. The results for grades 4 and 8 reading are in Table 10, and those for the math scores are in Table 11.

As with the previous results, the coefficient for the state effect only specifications are almost always larger for reasons noted above. Generally, the effects of local funding are the most robust in the sense of consistently attaining statistical significance and often being the largest in magnitude. However, as above, their magnitudes are still such that the association with test scores is very, very small.

State per pupil funding tends to be the smallest in magnitude and often does not attain statistical significance, with the exception of the grade 8 math scores. Federal funding has strong effects in the state effects only specifications, but generally has very weak effects when year effects are included.

\footnotetext{
${ }^{6}$ There are also small amounts of funds from private sources through fees and donations that we count as local.
} 
Table 10: Coefficient Estimates, Grade 4 and 8 Reading, Effects of Funding Source

Dependent Variable: NAEP Reading Score (absolute value of $t$-statistics in parentheses)

\begin{tabular}{|l|c|c|c|c|}
\hline \multicolumn{1}{|c|}{} & \multicolumn{2}{|c|}{ Grade 4 } & \multicolumn{2}{c|}{ Grade 8 } \\
\hline Variable & $\underline{(1)}$ & $\underline{(2)}$ & $\underline{(3)}$ & $\underline{(4)}$ \\
\hline Real federal revenue per pupil, & .6529 & .482 & .6409 & .7207 \\
lagged one year (\$1,000) & $(1.21)$ & $(0.57)$ & $(1.76)$ & $(1.19)$ \\
\hline Real state revenue per pupil, & .362 & -.1002 & .100 & .0434 \\
lagged one year (\$1,000) & $(2.31)$ & $(0.66)$ & $(0.84)$ & $(0.38)$ \\
\hline Real local revenue per pupil, & 1.0299 & .5758 & .3052 & .3286 \\
lagged one year (\$1,000) & $(6.39)$ & $(3.80)$ & $(2.55)$ & $(2.90)$ \\
\hline Demographics & yes & yes & yes & yes \\
\hline State effects & yes & yes & yes & yes \\
\hline Year effects & no & yes & no & yes \\
\hline $\mathrm{R}^{2}$ & .8877 & .9134 & .9371 & .9505 \\
\hline $\mathrm{N}$ & 523 & 523 & 436 & 436 \\
\hline
\end{tabular}

Table 11: Coefficient Estimates, Grade 4 and 8 Math, Effects of Funding Source Dependent Variable: NAEP Math Score (absolute value of $t$-statistics in parentheses)

\begin{tabular}{|l|c|c|c|c|}
\hline \multicolumn{1}{|c|}{} & \multicolumn{2}{|c|}{ Grade 4 } & \multicolumn{2}{c|}{ Grade 8 } \\
\hline Variable & $\underline{(1)}$ & $\underline{(2)}$ & $\underline{(3)}$ & $\underline{(4)}$ \\
\hline Real federal revenue per pupil, & 3.6484 & -.3461 & 3.4682 & -.8934 \\
lagged one year (\$1,000) & $(4.98)$ & $(0.42)$ & $(5.50)$ & $(0.89)$ \\
\hline Real state revenue per pupil, & .8357 & .0858 & 1.121 & .3458 \\
lagged one year (\$1,000) & $(4.19)$ & $(0.60)$ & $(6.42)$ & $(2.15)$ \\
\hline Real local revenue per pupil, & 1.1897 & .5033 & 1.2634 & .7316 \\
lagged one year (\$1,000) & $(6.01)$ & $(3.64)$ & $(7.31)$ & $(4.75)$ \\
\hline Demographics & yes & yes & yes & yes \\
\hline State effects & yes & yes & yes & yes \\
\hline Year effects & no & yes & no & yes \\
\hline $\mathrm{R}^{2}$ & .8952 & .9546 & .9193 & .9451 \\
\hline $\mathrm{N}$ & 484 & 484 & 517 & \\
\hline
\end{tabular}




\section{E. Revisiting the Productivity of Educational Funding}

This subsection revisits the productivity of educational funding over time with use of the cross-state panel of observations rather than with the national-level data, as in the previous section. These data provide over time as well as across state variation in funding and test scores to examine productivity. For each state and year, we compute productivity as above: NAEP test score points per $\$ 1,000$ of funding. We then estimate models as in equation (2).

$$
\mathrm{P}_{\mathrm{jt}}=\mathrm{a}_{0}+\mathrm{a}_{1} \mathrm{X}_{\mathrm{jt}}+\theta_{\mathrm{j}}+\delta_{\mathrm{t}}+\mathrm{u}_{\mathrm{jt}}
$$

where $\mathrm{j}$ indexes states, $\mathrm{t}$ indexes time. The term $\mathrm{P}_{\mathrm{jt}}$ is state $\mathrm{j}$ 's productivity at time $\mathrm{t}$ (where we estimate separate equations for each test), $\mathrm{u}_{\mathrm{jt}}$ is white noise, and $\mathrm{X}_{\mathrm{jt}}, \theta_{\mathrm{j}}$, and $\delta_{\mathrm{t}}$ are as above: a vector of demographics for state $\mathrm{j}$ at time $\mathrm{t}$, a vector of state effect dummy variables, and a vector of year effect dummy variables, respectively.

We report two specifications for each test score. The first is with only time dummies and the second also includes the demographics and the state dummies. Thus, we consider the time path of productivity, both with and without adjustment for demographics and state effects. Table 12 reports the findings for grades 4 and 8 reading scores. The "baseline" is mean productivity in the first year the test was given. Coefficients show the change in productivity from the baseline year, both with no adjustment (columns (1) and (3)) and with adjustment (columns (2) and (4)).

The time effect coefficients in Table 12 are all negative with most statistically significant. Generally, the coefficients become larger with time, until 2011 when they decline. This is consistent with the national level data on productivity, and corresponds to the decline in funding after the recession. Moreover, the magnitudes of the coefficients of columns (1) and (3) in Table 12 are quite consistent with national productivity declines found in the national data. 
Table 12: Productivity of Funding on Reading Scores, by Year, Grades 4 and 8 Dependent Variable: NAEP Reading Score per \$1,000 of School Funding (absolute value of $t$-statistics in parentheses)

\begin{tabular}{|c|c|c|c|c|}
\hline & \multicolumn{2}{|c|}{ Grade 4} & \multicolumn{2}{|c|}{ Grade 8} \\
\hline Year & (1) & (2) & (3) & (4) \\
\hline 1992 & $24.4235^{\mathrm{a}}$ & $24.4235^{\mathrm{a}}$ & & \\
\hline 1994 & $\begin{array}{l}-.8695 \\
(0.94)\end{array}$ & $\begin{array}{l}-.8686 \\
(2.74)\end{array}$ & & \\
\hline 1998 & $\begin{array}{c}-1.7158 \\
(1.85)\end{array}$ & $\begin{array}{c}-2.4483 \\
(5.32)\end{array}$ & $27.9202^{\mathrm{a}}$ & $27.9202^{\mathrm{a}}$ \\
\hline 2002 & $\begin{array}{c}-4.3905 \\
(4.86)\end{array}$ & $\begin{array}{l}-5.7622 \\
(11.26)\end{array}$ & $\begin{array}{c}-3.6477 \\
(3.40)\end{array}$ & $\begin{array}{l}-3.6646 \\
(11.14)\end{array}$ \\
\hline 2003 & $\begin{array}{c}-5.2197 \\
(5.98)\end{array}$ & $\begin{array}{l}-6.4491 \\
(12.08)\end{array}$ & $\begin{array}{c}-4.7267 \\
(4.60)\end{array}$ & $\begin{array}{l}-4.1996 \\
(12.05)\end{array}$ \\
\hline 2005 & $\begin{array}{c}-5.7519 \\
(6.59)\end{array}$ & $\begin{array}{l}-6.8210 \\
(13.90)\end{array}$ & $\begin{array}{c}-5.5221 \\
(5.37)\end{array}$ & $\begin{array}{l}-4.6342 \\
(12.07)\end{array}$ \\
\hline 2007 & $\begin{array}{c}-6.4392 \\
(7.38)\end{array}$ & $\begin{array}{l}-8.1799 \\
(14.21)\end{array}$ & $\begin{array}{c}-6.5185 \\
(6.34)\end{array}$ & $\begin{array}{l}-5.8904 \\
(13.34)\end{array}$ \\
\hline 2009 & $\begin{array}{c}-7.2994 \\
(8.37)\end{array}$ & $\begin{array}{l}-9.5670 \\
(15.36)\end{array}$ & $\begin{array}{c}-7.4351 \\
(7.23)\end{array}$ & $\begin{array}{c}-7.3969 \\
(14.71)\end{array}$ \\
\hline 2011 & $\begin{array}{c}-7.6469 \\
(8.76)\end{array}$ & $\begin{array}{c}-10.3871 \\
(14.64)\end{array}$ & $\begin{array}{c}-7.7497 \\
(7.54)\end{array}$ & $\begin{array}{r}-7.7747 \\
(15.37)\end{array}$ \\
\hline 2013 & $\begin{array}{c}-6.6353 \\
(7.61)\end{array}$ & $\begin{array}{l}-8.9815 \\
(10.70)\end{array}$ & $\begin{array}{c}-6.4754 \\
(6.30)\end{array}$ & $\begin{array}{c}-4.5775 \\
(5.73)\end{array}$ \\
\hline 2015 & $\begin{array}{c}-6.4536 \\
(7.40)\end{array}$ & $\begin{array}{c}-9.8629 \\
(12.10)\end{array}$ & $\begin{array}{c}-6.4809 \\
(6.30)\end{array}$ & $\begin{array}{l}-6.7137 \\
(10.52)\end{array}$ \\
\hline Demographics & no & yes & no & yes \\
\hline State effects & no & yes & no & yes \\
\hline $\mathrm{R}^{2}$ & .2621 & .9368 & .1633 & .9508 \\
\hline $\mathrm{N}$ & 523 & 523 & 436 & 436 \\
\hline
\end{tabular}

${ }^{\mathrm{a} B a s e l i n e ~ y e a r ~ f o r ~ e a c h ~ t e s t . ~}$

Table 13 presents the analogous results for grades 4 and 8 math scores. All year effect coefficients are negative, are mostly significant, and their magnitudes in columns (1) and (3) line up quite closely with the national data. Regarding columns (2) and (4) in both tables, these 
coefficients show that same pattern, but the magnitudes tend to be larger. This implies that if demographics and other state-level conditions remained the same as they were in the first year of the test, productivity would have dropped even more

Table 13: Productivity of Funding on Math Scores, by Year, Grades 4 and 8

Dependent Variable: NAEP Math Score per \$1,000 of School Funding (absolute value of t-statistics in parentheses)

\begin{tabular}{|c|c|c|c|c|}
\hline & \multicolumn{2}{|c|}{ Grade 4} & \multicolumn{2}{|c|}{ Grade 8} \\
\hline Year & (1) & (2) & (3) & (4) \\
\hline 1990 & & & $30.0736^{\mathrm{a}}$ & $30.0736^{\mathrm{a}}$ \\
\hline 1992 & $24.7569^{a}$ & $24.7569^{a}$ & $\begin{array}{c}-.17887 \\
(0.15)\end{array}$ & $\begin{array}{c}-.58662 \\
(1.46)\end{array}$ \\
\hline 1996 & $\begin{array}{c}-1.3355 \\
(1.39)\end{array}$ & $\begin{array}{c}-2.1153 \\
(4.75)\end{array}$ & $\begin{array}{c}-1.1689 \\
(0.98)\end{array}$ & $\begin{array}{c}-2.2341 \\
(3.79)\end{array}$ \\
\hline 2000 & $\begin{array}{c}-2.6333 \\
(2.70)\end{array}$ & $\begin{array}{l}-4.105 \\
(8.47)\end{array}$ & $\begin{array}{c}-3.2697 \\
(2.72)\end{array}$ & $\begin{array}{c}-5.2611 \\
(7.98)\end{array}$ \\
\hline 2003 & $\begin{array}{c}-4.0896 \\
(4.42)\end{array}$ & $\begin{array}{c}-5.1371 \\
(8.42)\end{array}$ & $\begin{array}{c}-5.6190 \\
(4.94)\end{array}$ & $\begin{array}{c}-7.7371 \\
(10.10)\end{array}$ \\
\hline 2005 & $\begin{array}{c}-4.4560 \\
(4.81)\end{array}$ & $\begin{array}{c}-5.7665 \\
(8.89)\end{array}$ & $\begin{array}{c}-6.2840 \\
(5.53)\end{array}$ & $\begin{array}{c}-8.6970 \\
(12.26)\end{array}$ \\
\hline 2007 & $\begin{array}{c}-5.2316 \\
(5.65)\end{array}$ & $\begin{array}{r}-6.7580 \\
(10.52)\end{array}$ & $\begin{array}{c}-7.1534 \\
(6.29)\end{array}$ & $\begin{array}{c}-10.2214 \\
(12.78)\end{array}$ \\
\hline 2009 & $\begin{array}{c}-6.1206 \\
(6.61)\end{array}$ & $\begin{array}{c}-7.9755 \\
(11.39)\end{array}$ & $\begin{array}{c}-8.0966 \\
(7.12)\end{array}$ & $\begin{array}{c}-11.5434 \\
(14.83)\end{array}$ \\
\hline 2011 & $\begin{array}{c}-6.4292 \\
(6.95)\end{array}$ & $\begin{array}{r}-8.5372 \\
(11.07)\end{array}$ & $\begin{array}{c}-8.4706 \\
(7.45)\end{array}$ & $\begin{array}{c}-12.5275 \\
(14.44)\end{array}$ \\
\hline 2013 & $\begin{array}{c}-5.2793 \\
(5.70)\end{array}$ & $\begin{array}{c}-7.6944 \\
(9.15)\end{array}$ & $\begin{array}{c}-7.2230 \\
(6.35)\end{array}$ & $\begin{array}{c}-11.763 \\
(12.19)\end{array}$ \\
\hline 2015 & $\begin{array}{c}-5.3076 \\
(5.73)\end{array}$ & $\begin{array}{c}-7.8027 \\
(8.95)\end{array}$ & $\begin{array}{c}-7.2777 \\
(6.40)\end{array}$ & $\begin{array}{c}-12.0277 \\
(11.75)\end{array}$ \\
\hline Demographics & no & yes & no & yes \\
\hline State effects & no & yes & no & yes \\
\hline $\mathrm{R}^{2}$ & .1632 & .9357 & .2416 & .9328 \\
\hline $\mathrm{N}$ & 484 & 484 & 517 & 517 \\
\hline
\end{tabular}

${ }^{\mathrm{a} B a s e l i n e ~ y e a r ~ f o r ~ e a c h ~ t e s t . ~}$ 


\section{Conclusion}

It is clear that educational productivity, as measured by NAEP test scores per dollar of funding, continues to decline. Though test scores did improve during the 2000s, this improvement was far outstripped by increased educational funding, causing further reductions in productivity. Our analysis of the cross-state panel shows positive and statistically significant associations of school funding to NAEP test scores, but with very small magnitudes. Our preferred estimates imply that the magnitude is so small that $\$ 1,000$ more of per pupil funding is associated with less than one point higher NAEP test scores (where scores average over 200). This is consistent with the continued decline in productivity that we verify in the cross-state data. Similar results hold for black student scores, implying that the increased funding has not served to raise minority outcomes or to reduce racial inequality in test scores. We examine the influence of federal, state, and local funding separately, and generally find the effect of local funding to be the largest and most robust. However, the magnitude of the effects remain very small.

While it is appropriate to be cautious regarding causality with respect to funding and outcomes, the continued decline in educational productivity seems very evident. Schools are predominantly government-sponsored organizations, often with little competition, and the literature is quite clear regarding incentive problems in these types of organizations. The lack of efficiency should not be surprising. We suggest looking for improvements in educational performance by turning to alternatives that embrace or emulate private-sector, competitive organizations. 


\section{References}

Betts, Julian B., "Does School Quality Matter? Evidence From the National Longitudinal Survey of Youth," Review of Economics and Statistics, 77(2), May 1995, pp. 231-250.

Card, David and Krueger, Alan B., "Does School Quality Matter? Returns to Education and the Characteristics of Public Schools in the United States," Journal of Political Economy, 100(1), February 1992, pp. 1-40.

Coleman, James S., Equality of Educational Opportunity, U.S. Department of Health, Education, and Welfare, 1966.

Currie, Janet and Thomas, Dunca, "Early Test Scores, School Quality and Socioeconomic Status: Long Run Effects on Wage and Employment Outcomes," in Research in Labor Economics:

Worker Wellbeing in a Changing Labor Market, v .20, 2001, p. 103-132.

Fredriksson, Peter; Ockert, Bjorn; and Oosterbeek, Hessel, "Long-Tern Effects of Class Size," Quarterly Journal of Economics, February 2013, pp. 249-285.

Garen, John, "Assessing the Literature on School Reform From an Entrepreneurship Perspective," Journal of Entrepreneurship and Public Policy, 5(3), 2016, pp. 383-403.

Glewwe, Paul; Hanushek, Eric A.; Humpage, Sarah D.; and Ravina, Renato, "School Resources and Educational Outcomes in Developing Countries: A Review of the Literature from 1990 to 2010," in Glewwe, Paul (ed.), Education Policy and Policy in Developing Countries, Chicago: University of Chicago Press, 2013, pp. 13-64.

Gustafsson, Jan-Eric, "What Do We Know About Effects of School Resources on Educational Results?," 10, Swedish Economic Policy Review, January 2003, pp. 77-110.

Hanushek, Eric A., 'The Economics of Schooling: Production and Efficiency in Public Schools," Journal of Economic Literature, 24(3), September 1986, pp. 1141-1177.

Hanushek, Eric A., "The Failure of Input-Based Schooling Policies,” Economic Journal, 113, February 2003, pp. 65-98.

Hanushek, Eric A.; Ruhose, Jens; and Woessmann, Ledger, "Economic Gains from Education Reform in the US States," Journal of Human Capital, 11(4), Winter 2017, p. 447-486.

Heckman, James; Stixrud, Jora ; and Urzua, Sergio (2006), "The Effect of Cognitive and Noncognitive Abilities on Labor Market Outcomes and Social Behavior,"Journal of Labor Economics, Vol. 24 No. 3, pp. 411-482.

Hoxby, Caroline M., "Productivity in Education: The Quintessential Upstream Industry," Southern Economic Journal, 71(2), 2004, pp. 209-231. 
Jackson, C. Kirabo; Johnson, Rucker C.; and Persico, Claudia, "The Effects of School Spending on Educational and Economic Outcomes: Evidence from School Finance Reforms," Quarterly Journal of Economics, 131(1), February 2016, pp. 157-218.

Merrifield, John, “The Potential for System-Friendly K-12 Reform," Cato Journal, Vol. 29, No. 2, Spring/Summer 2009.

National Center for Educational Statistics, About NAEP, last updated May 10, 2017, https://nces.ed.gov/nationsreportcard/about/.

National Center for Educational Statistics, About State NAEP, https://nces.ed.gov/nationsreportcard/about/state.aspx, electronic data at https://nces.ed.gov/nationsreportcard/naepdata/dataset.aspx

National Center for Educational Statistics, Digest of Educational Statistics, https://nces.ed.gov/programs/digest/, electronic data at https://nces.ed.gov/programs/digest/current_tables.asp.

National Center for Educational Statistics, The Nation's Report Card: Trends in Academic Progress 2012, U.S. Department of Education, https://nces.ed.gov/nationsreportcard/subject/publications/main2012/pdf/2013456.pdf, electronic data at https://nces.ed.gov/nationsreportcard/lttdata/. 


\section{Appendix}

Table A1: NAEP National Reading and Mathematics Scores

Panel (a): Reading NAEP Scores and Gains from 1971
(1)
(2)
(3)
(4)

\begin{tabular}{|c|c|c|c|c|}
\hline Year & Gr 4 Read & Gr 4 Gain from 1971 & Gr 8 Read & Gr 8 Gain from 1971 \\
\cline { 2 - 5 } & 208 & 0 & 255 & 0 \\
\hline 1971 & 210 & 2 & 256 & 1 \\
\hline 1980 & 215 & 7 & 258 & 3 \\
\hline 1984 & 211 & 3 & 257 & 2 \\
\hline 1988 & 212 & 4 & 257 & 2 \\
\hline 1990 & 209 & 1 & 257 & 2 \\
\hline 1992 & 211 & 3 & 260 & 5 \\
\hline 1994 & 211 & 3 & 258 & 3 \\
\hline 1996 & 212 & 4 & 258 & 3 \\
\hline 1999 & 212 & 4 & 259 & 4 \\
\hline 2004 & 216 & 8 & 257 & 2 \\
\hline 2008 & 220 & 12 & 260 & 5 \\
\hline 2012 & 221 & 13 & 263 & 8 \\
\hline Mean & 212.92 & & 258.09 & \\
\hline
\end{tabular}

Panel (b): Math NAEP Scores and Gains from 1978

\begin{tabular}{|c|c|c|c|c|c|}
\hline & $(5)$ & $(6)$ & $(7)$ & $(8)$ \\
\hline Year & Gr 4 Math & Gr 4 Gain from 1978 & Gr 8 Math & Gr 8 Gain from 1978 \\
\hline 1978 & 219 & 0 & 264 & 0 \\
\hline 1982 & 219 & 0 & 269 & 5 \\
\hline 1986 & 222 & 3 & 269 & 5 \\
\hline 1990 & 230 & 11 & 270 & 6 \\
\hline 1992 & 230 & 11 & 273 & 9 \\
\hline 1994 & 231 & 12 & 274 & 10 \\
\hline 1996 & 231 & 12 & 274 & 10 \\
\hline 1999 & 232 & 13 & 276 & 12 \\
\hline 2004 & 239 & 20 & 279 & 15 \\
\hline 2008 & 243 & 24 & 281 & 17 \\
\hline 2012 & 244 & 25 & 285 & 21 \\
\hline Mean & 230.80 & & 274.08 & \\
\hline
\end{tabular}

Source: National Center for Educational Statistics, The Nation's Report Card, https://nces.ed.gov/nationsreportcard/lttdata/. 
Table A2: Real School Revenue and Expenditure, U.S., 2016 \$

\begin{tabular}{|c|c|c|c|c|c|c|c|}
\hline Year & $\begin{array}{c}\text { Total } \\
\text { Revenue }\end{array}$ & $\begin{array}{c}\text { Revenue, } \\
\text { Federal }\end{array}$ & $\begin{array}{c}\text { Revenue, } \\
\text { State }\end{array}$ & $\begin{array}{c}\text { Revenue, } \\
\text { Local }\end{array}$ & $\begin{array}{c}\text { Total } \\
\text { Expenditure }\end{array}$ & $\begin{array}{c}\text { Current } \\
\text { Expenditure }\end{array}$ & $\begin{array}{l}\text { Instructional } \\
\text { Expenditure }\end{array}$ \\
\hline 1971 & 5748 & 485 & 2248 & 3015 & 5748 & 4990 & \\
\hline 1972 & 6232 & 557 & 2385 & 3291 & 5938 & 5211 & \\
\hline 1973 & 6161 & 535 & 2447 & 3179 & 6034 & 5368 & \\
\hline 1974 & 6238 & 528 & 2583 & 3127 & 6056 & 5361 & \\
\hline 1975 & 6381 & 575 & 2680 & 3126 & 6351 & 5610 & \\
\hline 1976 & 6706 & 595 & 2976 & 3134 & 6596 & 5844 & \\
\hline 1977 & 6731 & 592 & 2907 & 3229 & 6628 & 5976 & \\
\hline 1978 & 6880 & 650 & 2958 & 3272 & 6779 & 6171 & \\
\hline 1979 & 6837 & 668 & 3118 & 3050 & 6709 & 6134 & \\
\hline 1980 & 6776 & 665 & 3172 & 2940 & 6670 & 6084 & \\
\hline 1981 & 6837 & 630 & 3238 & 2968 & 6679 & 6092 & \\
\hline 1982 & 6848 & 509 & 3259 & 3080 & 6850 & 6280 & \\
\hline 1983 & 7156 & 508 & 3428 & 3220 & 7148 & 6594 & \\
\hline 1984 & 7418 & 505 & 3545 & 3369 & 7428 & 6791 & \\
\hline 1985 & 7811 & 518 & 3821 & 3471 & 7708 & 7187 & \\
\hline 1986 & 8284 & 554 & 4089 & 3640 & 8156 & 7619 & \\
\hline 1987 & 8425 & 539 & 4190 & 3696 & 8440 & 7779 & 4793 \\
\hline 1988 & 8598 & 543 & 4260 & 3795 & 8744 & 7966 & 4955 \\
\hline 1989 & 9248 & 573 & 4420 & 4255 & 9171 & 8337 & 5074 \\
\hline 1990 & 9446 & 575 & 4450 & 4421 & 9637 & 8526 & 5143 \\
\hline 1991 & 9549 & 589 & 4503 & 4457 & 9809 & 8638 & 5226 \\
\hline 1992 & 9544 & 630 & 4426 & 4488 & 9807 & 8593 & 5227 \\
\hline 1993 & 9606 & 670 & 4399 & 4537 & 9812 & 8571 & 5236 \\
\hline 1994 & 9693 & 683 & 4377 & 4633 & 9884 & 8626 & 5277 \\
\hline 1995 & 9752 & 663 & 4560 & 4528 & 9961 & 8707 & 5375 \\
\hline 1996 & 9815 & 652 & 4662 & 4501 & 10016 & 8702 & 5372 \\
\hline 1997 & 10006 & 659 & 4803 & 4544 & 10271 & 8861 & 5482 \\
\hline 1998 & 10406 & 709 & 5032 & 4665 & 10672 & 9113 & 5635 \\
\hline 1999 & 10753 & 759 & 5241 & 4753 & 11015 & 9376 & 5782 \\
\hline 2000 & 11091 & 806 & 5491 & 4794 & 11358 & 9632 & 5948 \\
\hline 2001 & 11523 & 835 & 5730 & 4957 & 11794 & 10001 & 6153 \\
\hline 2002 & 11740 & 928 & 5780 & 5032 & 12184 & 10309 & 6343 \\
\hline 2003 & 11910 & 1015 & 5798 & 5096 & 12310 & 10489 & 6433 \\
\hline 2004 & 12093 & 1097 & 5690 & 5306 & 12403 & 10558 & 6477 \\
\hline 2005 & 12284 & 1129 & 5756 & 5399 & 12582 & 10705 & 6549 \\
\hline 2006 & 12620 & 1153 & 5870 & 5598 & 12817 & 10898 & 6636 \\
\hline 2007 & 13048 & 1107 & 6190 & 5751 & 13200 & 11196 & 6825 \\
\hline 2008 & 13224 & 1079 & 6392 & 5752 & 13492 & 11462 & 6971 \\
\hline 2009 & 13453 & 1287 & 6279 & 5886 & 13859 & 11784 & 7177 \\
\hline 2010 & 13323 & 1695 & 5793 & 5835 & 13540 & 11718 & 7163 \\
\hline 2011 & 13028 & 1629 & 5752 & 5647 & 13031 & 11370 & 6955 \\
\hline 2012 & 12676 & 1289 & 5730 & 5657 & 12703 & 11126 & 6776 \\
\hline
\end{tabular}

Source: National Center for Educational Statistics, Digest of Educational Statistics, https://nces.ed.gov/programs/digest/current_tables.asp. 
Table A3: Productivity. NAEP Points per $\$ 1000$ of Education Revenue

\begin{tabular}{|l|c|c|c|c|}
\hline$\underline{\text { Year }}$ & Grade 4 Read & Grade 8 Read & Grade 4 Math & Grade 8 Math \\
\hline 1971 & 36.2 & 44.4 & & \\
\hline 1975 & 32.9 & 40.1 & & \\
\hline 1978 & & & 31.8 & 38.4 \\
\hline 1980 & 31.7 & 38.1 & & \\
\hline 1982 & & & 32.0 & 39.2 \\
\hline 1984 & 28.4 & 34.7 & & \\
\hline 1986 & & & 26.8 & 32.5 \\
\hline 1988 & 24.7 & 29.9 & & \\
\hline 1990 & 22.1 & 27.2 & 24.3 & 28.6 \\
\hline 1992 & 22.1 & 27.2 & 24.1 & 28.6 \\
\hline 1994 & 21.8 & 26.6 & 23.8 & 28.3 \\
\hline 1996 & 21.6 & 26.3 & 23.5 & 27.9 \\
\hline 1999 & 19.7 & 24.1 & 21.6 & 25.7 \\
\hline 2004 & 17.9 & 21.2 & 19.8 & 23.1 \\
\hline 2008 & 16.6 & 19.6 & 18.4 & 21.3 \\
\hline 2012 & 17.4 & 20.7 & 19.2 & 22.5 \\
\hline
\end{tabular}

Source: National Center for Educational Statistics, The Nation's Report Card, https://nces.ed.gov/nationsreportcard/lttdata/ and Digest of Educational Statistics, https://nces.ed.gov/programs/digest/current_tables.asp.

Table A4: Years of State-Based NAEP Assessments

\begin{tabular}{|l|c|c|c|c|}
\hline Year & Grade 4 Reading & Grade 8 Reading & Grade 4 Math & Grade 8 Math \\
\hline 1990 & & & & selected states \\
\hline 1992 & selected states & selected states & selected states & \\
\hline 1994 & selected states & & & \\
\hline 1996 & & & selected states & selected states \\
\hline 1998 & selected states & selected states & & \\
\hline 2000 & & & selected states & selected states \\
\hline 2002 & selected states & selected states & & \\
\hline 2003 & all states & all states & all states & all states \\
\hline 2005 & all states & all states & all states & all states \\
\hline 2007 & all states & all states & all states & all states \\
\hline 2009 & all states & all states & all states & all states \\
\hline 2011 & all states & all states & all states & all states \\
\hline 2013 & all states & all states & all states & all states \\
\hline 2015 & all states & all states & all states & all states \\
\hline
\end{tabular}

Source: National Center for Educational Statistics, The Nation's Report Card. 
Table A5: Coefficient Estimates, Grade 4 Reading Equation*

Dependent Variable: NAEP Grade 4 Reading Score (absolute value of t-statistics in parentheses)

\begin{tabular}{|c|c|c|c|c|}
\hline Variable & (1) & (2) & (3) & (4) \\
\hline $\begin{array}{l}\text { Real revenue per pupil } \\
\text { (lagged one year) }\end{array}$ & $\begin{array}{c}.0006119 \\
(6.16)\end{array}$ & $\begin{array}{c}.0002567 \\
(2.94)\end{array}$ & $\begin{array}{c}.0006992 \\
(6.51)\end{array}$ & $\begin{array}{c}.0002549 \\
(2.18)\end{array}$ \\
\hline Percent White & & $\begin{array}{c}.1639922 \\
(7.92)\end{array}$ & $\begin{array}{l}-.2041423 \\
\quad(3.79)\end{array}$ & $\begin{array}{l}-.0031506 \\
\quad(0.06)\end{array}$ \\
\hline Percent Black & & $\begin{array}{c}-.0901961 \\
(3.92)\end{array}$ & $\begin{array}{l}-.573056 \\
(7.91)\end{array}$ & $\begin{array}{l}-.4595293 \\
\quad(6.53)\end{array}$ \\
\hline Percent Hispanic & & $\begin{array}{c}.1033978 \\
(4.00)\end{array}$ & $\begin{array}{c}.0380793 \\
(1.31)\end{array}$ & $\begin{array}{l}.0245305 \\
(0.94)\end{array}$ \\
\hline $\begin{array}{l}\text { Percent School Lunch } \\
\text { Eligible }\end{array}$ & & $\begin{array}{l}-.156467 \\
(6.45)\end{array}$ & $\begin{array}{l}-.0027509 \\
(0.09)\end{array}$ & $\begin{array}{c}-.13664 \\
(3.42)\end{array}$ \\
\hline $\begin{array}{l}\text { Pct. English Language } \\
\text { Learners }\end{array}$ & & $\begin{array}{l}-.3307864 \\
\quad(2.63)\end{array}$ & $\begin{array}{l}-.0077471 \\
\quad(0.08)\end{array}$ & $\begin{array}{l}-.02928 \\
(0.32)\end{array}$ \\
\hline $\begin{array}{l}\text { Pct. English Language } \\
\text { Learners assessed }\end{array}$ & & $\begin{array}{c}.1026955 \\
(0.67)\end{array}$ & $\begin{array}{l}-.1103212 \\
(0.97)\end{array}$ & $\begin{array}{l}-.1582443 \\
\quad(1.44)\end{array}$ \\
\hline $\begin{array}{l}\text { Pct. English Language } \\
\text { Learners accommodated }\end{array}$ & & $\begin{array}{l}.3362454 \\
(3.24)\end{array}$ & $\begin{array}{c}.1116681 \\
(1.32)\end{array}$ & $\begin{array}{c}.2991223 \\
(2.87)\end{array}$ \\
\hline $\begin{array}{l}\text { Pct. Students with } \\
\text { Disability }\end{array}$ & & $\begin{array}{l}.4376456 \\
(3.39)\end{array}$ & $\begin{array}{c}.3860687 \\
(3.91)\end{array}$ & $\begin{array}{c}.2853661 \\
(2.86)\end{array}$ \\
\hline $\begin{array}{l}\text { Pct. Students with } \\
\text { Disability assessed }\end{array}$ & & $\begin{array}{l}-.8676102 \\
\quad(5.28)\end{array}$ & $\begin{array}{l}-.7096491 \\
\quad(6.14)\end{array}$ & $\begin{array}{l}-.5043579 \\
\quad(4.60)\end{array}$ \\
\hline $\begin{array}{l}\text { Pct. Students with } \\
\text { Disability accommodated }\end{array}$ & & $\begin{array}{l}1.17883 \\
(8.11)\end{array}$ & $\begin{array}{c}.4411311 \\
(3.83)\end{array}$ & $\begin{array}{c}-.06893 \\
(0.58)\end{array}$ \\
\hline State effects & no & no & yes & yes \\
\hline Year effects & no & no & no & yes \\
\hline $\mathrm{R}^{2}$ & 0.0680 & 0.6432 & 0.8853 & 0.9108 \\
\hline $\mathrm{N}$ & 523 & 523 & 523 & 523 \\
\hline
\end{tabular}

*For sources and variable definitions, see Table 2. 
Table A6: Coefficient Estimates, Grade 8 Reading Equation*

Dependent Variable: NAEP Grade 8 Reading Score (absolute value of $t$-statistics in parentheses)

\begin{tabular}{|c|c|c|c|c|}
\hline Variable & (1) & $\underline{(2)}$ & (3) & $\underline{(4)}$ \\
\hline $\begin{array}{l}\text { Real revenue per pupil } \\
\text { (lagged one year) }\end{array}$ & $\begin{array}{l}.0003064 \\
(3.24)\end{array}$ & $\begin{array}{l}.0001131 \\
(1.57)\end{array}$ & $\begin{array}{l}.0002478 \\
(3.09)\end{array}$ & $\begin{array}{l}.0002033 \\
(2.35)\end{array}$ \\
\hline Percent White & & $\begin{array}{l}.1534081 \\
(9.78)\end{array}$ & $\begin{array}{c}.0788794 \\
(1.49)\end{array}$ & $\begin{array}{l}.097364 \\
(1.80)\end{array}$ \\
\hline Percent Black & & $\begin{array}{c}-.0741953 \\
(4.17)\end{array}$ & $\begin{array}{c}-.3238809 \\
(4.49)\end{array}$ & $\begin{array}{l}-.2197445 \\
(3.16)\end{array}$ \\
\hline Percent Hispanic & & $\begin{array}{l}.1035303 \\
(4.94)\end{array}$ & $\begin{array}{l}.0542785 \\
(0.94)\end{array}$ & $\begin{array}{c}.0465352 \\
(0.88)\end{array}$ \\
\hline $\begin{array}{l}\text { Percent School Lunch } \\
\text { Eligible }\end{array}$ & & $\begin{array}{c}-.221742 \\
(10.28)\end{array}$ & $\begin{array}{l}.1793948 \\
(6.26)\end{array}$ & $\begin{array}{l}.004827 \\
(0.14)\end{array}$ \\
\hline $\begin{array}{l}\text { Pct. English Language } \\
\text { Learners }\end{array}$ & & $\begin{array}{l}.2975124 \\
(1.51)\end{array}$ & $\begin{array}{l}.2615761 \\
(2.12)\end{array}$ & $\begin{array}{l}.045122 \\
(0.37)\end{array}$ \\
\hline $\begin{array}{l}\text { Pct. English Language } \\
\text { Learners assessed }\end{array}$ & & $\begin{array}{l}-.8038768 \\
(3.68)\end{array}$ & $\begin{array}{c}-.4592573 \\
(3.09)\end{array}$ & $\begin{array}{l}-.3011538 \\
(2.12)\end{array}$ \\
\hline $\begin{array}{l}\text { Pct. English Language } \\
\text { Learners accommodated }\end{array}$ & & $\begin{array}{l}.7371854 \\
(7.03)\end{array}$ & $\begin{array}{c}.3659163 \\
(4.68)\end{array}$ & $\begin{array}{l}.228682 \\
(2.39)\end{array}$ \\
\hline $\begin{array}{l}\text { Pct. Students with } \\
\text { Disability }\end{array}$ & & $\begin{array}{c}.003481 \\
(0.03)\end{array}$ & $\begin{array}{l}.1903165 \\
(2.11)\end{array}$ & $\begin{array}{c}.3077137 \\
(3.37)\end{array}$ \\
\hline $\begin{array}{l}\text { Pct. Students with } \\
\text { Disability assessed }\end{array}$ & & $\begin{array}{l}-.7712474 \\
(5.66)\end{array}$ & $\begin{array}{l}-.7275993 \\
(7.55)\end{array}$ & $\begin{array}{l}-.8404803 \\
(8.98)\end{array}$ \\
\hline \begin{tabular}{|l|} 
Pct. Students with \\
Disability accommodated
\end{tabular} & & $\begin{array}{c}.8434071 \\
(8.32)\end{array}$ & $\begin{array}{l}.3534601 \\
(3.13)\end{array}$ & $\begin{array}{l}.2961936 \\
(3.04)\end{array}$ \\
\hline State effects & no & no & yes & yes \\
\hline Year effects & no & no & no & yes \\
\hline $\mathrm{R}^{2}$ & 0.0236 & 0.7636 & 0.9366 & 0.9499 \\
\hline $\mathrm{N}$ & 436 & 436 & 436 & 436 \\
\hline
\end{tabular}

*For sources and variable definitions, see Table 2. 
Table A7: Coefficient Estimates, Grade 4 Math Equation*

Dependent Variable: NAEP Grade 4 Math Score (absolute value of t-statistics in parentheses)

\begin{tabular}{|c|c|c|c|c|}
\hline Variable & $\underline{(1)}$ & $\underline{(2)}$ & (3) & (4) \\
\hline $\begin{array}{l}\text { Real revenue per pupil } \\
\text { (lagged one year) }\end{array}$ & $\begin{array}{l}.0012101 \\
(9.39)\end{array}$ & $\begin{array}{c}.0002094 \\
(1.97)\end{array}$ & $\begin{array}{c}.0012159 \\
(8.14)\end{array}$ & $\begin{array}{c}.0002902 \\
(2.55)\end{array}$ \\
\hline Percent White & & $\begin{array}{l}.107246 \\
(3.68)\end{array}$ & $\begin{array}{l}.2917496 \\
(2.92)\end{array}$ & $\begin{array}{c}.1228174 \\
(1.64)\end{array}$ \\
\hline Percent Black & & $\begin{array}{c}-.136853 \\
(4.49)\end{array}$ & $\begin{array}{l}.0326449 \\
(0.36)\end{array}$ & $\begin{array}{c}-.2407664 \\
(2.58)\end{array}$ \\
\hline Percent Hispanic & & $\begin{array}{l}-.0241265 \\
(0.59)\end{array}$ & $\begin{array}{c}.0686704 \\
(0.67)\end{array}$ & $\begin{array}{c}.0880234 \\
(1.26)\end{array}$ \\
\hline $\begin{array}{l}\text { Percent School Lunch } \\
\text { Eligible }\end{array}$ & & $\begin{array}{c}-.0874069 \\
(2.75)\end{array}$ & $\begin{array}{c}.3015466 \\
(6.77)\end{array}$ & $\begin{array}{c}-.117845 \\
(2.88)\end{array}$ \\
\hline $\begin{array}{l}\text { Pct. English Language } \\
\text { Learners }\end{array}$ & & $\begin{array}{l}-1.571452 \\
(5.42)\end{array}$ & $\begin{array}{l}-.7669221 \\
(3.09)\end{array}$ & $\begin{array}{l}-.4131196 \\
(2.47)\end{array}$ \\
\hline $\begin{array}{l}\text { Pct. English Language } \\
\text { Learners assessed }\end{array}$ & & $\begin{array}{c}1.869721 \\
(5.95)\end{array}$ & $\begin{array}{c}1.037856 \\
(4.21)\end{array}$ & $\begin{array}{c}.3045977 \\
(1.77)\end{array}$ \\
\hline $\begin{array}{l}\text { Pct. English Language } \\
\text { Learners accommodated }\end{array}$ & & $\begin{array}{c}.2175722 \\
(1.27)\end{array}$ & $\begin{array}{l}.011931 \\
(0.08)\end{array}$ & $\begin{array}{l}.103427 \\
(1.19)\end{array}$ \\
\hline $\begin{array}{l}\text { Pct. Students with } \\
\text { Disability }\end{array}$ & & $\begin{array}{c}.0801938 \\
(0.37)\end{array}$ & $\begin{array}{l}.3870232 \\
(2.11)\end{array}$ & $\begin{array}{c}.2729143 \\
(2.07)\end{array}$ \\
\hline $\begin{array}{l}\text { Pct. Students with } \\
\text { Disability assessed }\end{array}$ & & $\begin{array}{c}-.648937 \\
(2.35)\end{array}$ & $\begin{array}{c}-.5717215 \\
(2.64)\end{array}$ & $\begin{array}{l}-.39699 \\
(2.70)\end{array}$ \\
\hline $\begin{array}{l}\text { Pct. Students with } \\
\text { Disability accommodated }\end{array}$ & & $\begin{array}{c}1.930095 \\
(10.69)\end{array}$ & $\begin{array}{c}1.145408 \\
(7.24)\end{array}$ & $\begin{array}{c}.1124339 \\
(0.93)\end{array}$ \\
\hline State effects & no & no & yes & yes \\
\hline Year effects & no & no & no & yes \\
\hline $\mathrm{R}^{2}$ & 0.1546 & 0.6981 & 0.8916 & 0.9538 \\
\hline $\mathrm{N}$ & 484 & 484 & 484 & 484 \\
\hline
\end{tabular}

*For sources and variable definitions, see Table 2. 
Table A8: Coefficient Estimates, Grade 8 Math Equation*

Dependent Variable: NAEP Grade 8 Math Score (absolute value of t-statistics in parentheses)

\begin{tabular}{|c|c|c|c|c|}
\hline Variable & (1) & (2) & (3) & (4) \\
\hline $\begin{array}{l}\text { Real revenue per pupil } \\
\text { (lagged one year) }\end{array}$ & $\begin{array}{l}.0011562 \\
(8.74)\end{array}$ & $\begin{array}{l}.000437 \\
(3.41)\end{array}$ & $\begin{array}{l}.0013896 \\
(10.78)\end{array}$ & $\begin{array}{c}.0005193 \\
(4.00)\end{array}$ \\
\hline Percent White & & $\begin{array}{c}.1618097 \\
(5.58)\end{array}$ & $\begin{array}{c}.3190889 \\
(3.10)\end{array}$ & $\begin{array}{c}.3438009 \\
(3.67)\end{array}$ \\
\hline Percent Black & & $\begin{array}{c}-.2167494 \\
(6.67)\end{array}$ & $\begin{array}{c}.0898037 \\
(0.66)\end{array}$ & $\begin{array}{c}-.1600979 \\
(1.30)\end{array}$ \\
\hline Percent Hispanic & & $\begin{array}{l}.0550193 \\
(1.45)\end{array}$ & $\begin{array}{l}.5961319 \\
(4.66)\end{array}$ & $\begin{array}{l}.3799881 \\
(3.49)\end{array}$ \\
\hline $\begin{array}{l}\text { Percent School Lunch } \\
\text { Eligible }\end{array}$ & & $\begin{array}{l}-.1101374 \\
(3.16)\end{array}$ & $\begin{array}{l}.295285 \\
(8.71)\end{array}$ & $\begin{array}{l}.0235089 \\
(0.49)\end{array}$ \\
\hline $\begin{array}{l}\text { Pct. English Language } \\
\text { Learners }\end{array}$ & & $\begin{array}{l}-.8544714 \\
(2.07)\end{array}$ & $\begin{array}{c}-.010864 \\
(0.04)\end{array}$ & $\begin{array}{l}-.1644773 \\
(0.74)\end{array}$ \\
\hline $\begin{array}{l}\text { Pct. English Language } \\
\text { Learners assessed }\end{array}$ & & $\begin{array}{c}1.028798 \\
(2.33)\end{array}$ & $\begin{array}{c}-.0082677 \\
(0.03)\end{array}$ & $\begin{array}{c}.0061493 \\
(0.03)\end{array}$ \\
\hline $\begin{array}{l}\text { Pct. English Language } \\
\text { Learners accommodated }\end{array}$ & & $\begin{array}{c}.0870519 \\
(0.23)\end{array}$ & $\begin{array}{l}-.2693493 \\
(1.07)\end{array}$ & $\begin{array}{c}.0159452 \\
(0.07)\end{array}$ \\
\hline $\begin{array}{l}\text { Pct. Students with } \\
\text { Disability }\end{array}$ & & $\begin{array}{l}-.2139781 \\
(1.02)\end{array}$ & $\begin{array}{c}.3261958 \\
(2.41)\end{array}$ & $\begin{array}{l}.1200237 \\
(0.97)\end{array}$ \\
\hline $\begin{array}{l}\text { Pct. Students with } \\
\text { Disability assessed }\end{array}$ & & $\begin{array}{l}-.9922245 \\
(4.05)\end{array}$ & $\begin{array}{l}-.7905019 \\
(5.30)\end{array}$ & $\begin{array}{l}-.4907514 \\
(3.61)\end{array}$ \\
\hline \begin{tabular}{|l|} 
Pct. Students with \\
Disability accommodated
\end{tabular} & & $\begin{array}{l}1.852907 \\
(10.33)\end{array}$ & $\begin{array}{l}.705193 \\
(5.65)\end{array}$ & $\begin{array}{l}.14871 \\
(1.13)\end{array}$ \\
\hline State effects & no & no & yes & yes \\
\hline Year effects & no & no & no & yes \\
\hline $\mathrm{R}^{2}$ & 0.1291 & 0.6638 & 0.9171 & 0.9443 \\
\hline $\mathrm{N}$ & 517 & 517 & 517 & 517 \\
\hline
\end{tabular}

*For sources and variable definitions, see Table 2. 